Check for updates

Cite this: RSC Adv., 2020, 10, 30265

\title{
Mannich bases derived from lawsone and their metal complexes: synthetic strategies and biological properties
}

\author{
Abolfazl Olyaei, (DD *a Mahdieh Sadeghpour ${ }^{\mathrm{b}}$ and Mehdi Khalaj (D) $^{\mathrm{c}}$ \\ Lawsone (2-hydroxynaphthalene-1,4-dione) is a natural product which shows significant biological activity. \\ Aminomethylnaphthoquinone Mannich bases derived from lawsone constitute an interesting class of \\ naphthoquinones and/or their metal complexes have demonstrated a series of important biological \\ properties. So, this review aimed to document the publications concerning the synthesis of \\ aminomethylnaphthoquinone Mannich bases from lowsone, aldehydes and amines and their metal \\ complexes using different conditions, and investigation of their applications.
}

Received 30th June 2020

Accepted 30th July 2020

DOI: 10.1039/d0ra05717g

rsc.li/rsc-advances

Hydroxy-1,4-naphthoquinone, or lawsone, or hennotannic acid, has been known for the past 4000 years, is one of the simplest naturally occurring naphthoquinones. It is a red-orange dye, classified as Natural Orange 6 (C.I.75480), present in the leaves of the henna plant (Lawsonia spp., family Lythraceae) as well as in the flower of water hyacinth (Eichhornia crassipes) and in jewelweed Impatiens balsamina. ${ }^{4,5}$ It is traditionally used for coloring hair and dying nails, skin, wool and cotton. ${ }^{6-10}$ Besides it has several other uses including antiaging additive to vulcanized natural rubber ${ }^{11}$ skin protection from ultraviolet radiation, ${ }^{12,13}$ oxidation of chlorinated compounds, ${ }^{14,15}$ corrosion inhibition for steel, ${ }^{16,17}$ and sensitive colorimetric and electrochemical sensor for anions. ${ }^{18}$ Extracts of henna are widely used in folk medicine to treat burn

'Department of Chemistry, Buinzahra Branch, Islamic Azad University, Buinzahra, Iran

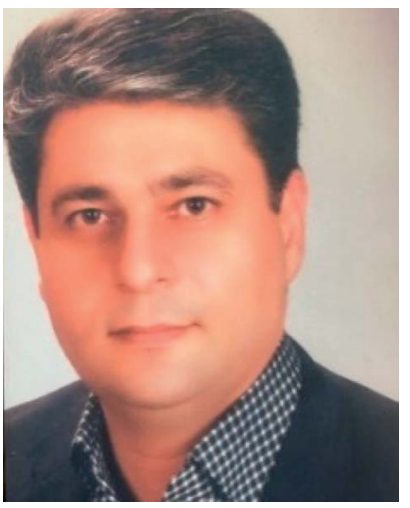

Abolfazl Olyaei Associate professor Dr Abolfazl Olyaei was born in Tabriz, Iran in 1975. He received his B.Sc. degree in pure chemistry in the University of Tabriz in 1999. He received his M.Sc. in 2001 and his PhD in 2007 in organic chemistry under supervision of of Professor Mehdi Ghandi Both in Tehran University, Tehran, Iran. He was as an assistance professor in the university of Payame Noor in 2007 and in now he is an associate professor in this university. His research interests include organic synthesis, organic materials, green chemistry, catalysis and organo catalysis and application of materials and organo materials in different sciences.

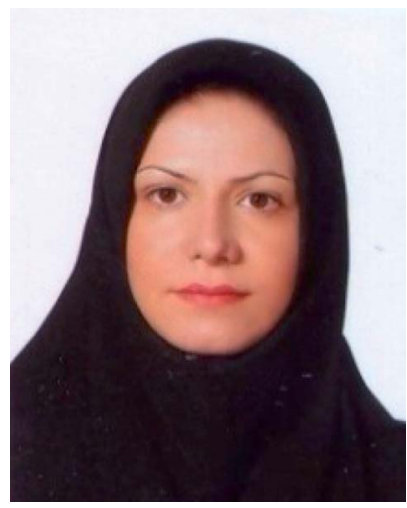

Mahdieh Sadeghpour Associate professor Dr Mahdieh Sadeghpour was born in Qazvin, Iran, in 1978. She received his B.Sc. degree in pure chemistry in Alzahra University, Tehran, Iran in 2001. And her M.Sc. in 2004 in organic chemistry under supervision of Associate Professor Nikoo Sedighi in Tehran University, Tehran, Iran. She graduated from $P h D$ in 2009 in organic chemistry under supervision of professor Abbas Shokravi and associate professor Abolfazl olyaei, in organic chemistry in Kharazmi University, Tehran, Iran. Now she is an Associate Professor in Islamic Azad University of Takestan. Her research interests include organic synthesis, green chemistry and application of materials and nanomaterials in different sciences. 
wounds infected by microorganisms ${ }^{19}$ due to its antibacterial properties $^{\mathbf{2 0}}$ as well as headaches, lumbago, bronchitis, ophthalmia, syphilis, sores and amenorrhoea. ${ }^{21}$ The classical Mannich reaction is one of the most important carbon-carbon bond-forming reactions in organic synthesis because of its atomeconomy advantages and application in biologically active molecule syntheses. However, a three-component condensation between structurally diverse substrates containing at least one acidic hydrogen atom, an aldehyde component and an amine reagent leads to Mannich bases. This multicomponent reaction usually occurs under acid catalysis, although catalysis is not mandatory.

3-(Aminomethyl)-2-hydroxy-1,4-naphthoquinones known as aminonaphthoquinone Mannich bases, constitute an interesting class of naphthoquinones and/or their metal complexes have demonstrated a series of important biological properties such as anticancer, ${ }^{22}$ antimalarial, ${ }^{23}$ antimolluscicidal, ${ }^{24}$ antibacterial, ${ }^{25}$ cholinesterase inhibitors, ${ }^{26}$ leishmanicidal, ${ }^{27}$ antiviral, ${ }^{28}$ antifungal, ${ }^{29}$ anti parasitic ${ }^{30}$ activities and they have also been employed as fluorescent compounds and dyes. ${ }^{31}$ Because of their prevalent applications, several methods have been reported for the synthesis of these important compounds and their metal complexes. This review will summarize the reported methods for the synthesis of aminonaphthoquinone Mannich base derivatives by multicomponent reactions of lawsone with a non-enolizable aldehyde and a primary or secondary amine via the Mannich reaction and their metal complexes using different conditions, and applications of these compounds.

\section{Synthesis of aminomethylnaphthoquinone Mannich bases}

\subsection{Uncatalyzed reactions}

The first synthesis of 2-hydroxy-3-aminomethyl-1,4naphthoquinones $\mathbf{1}$ by the Mannich reaction has been reported

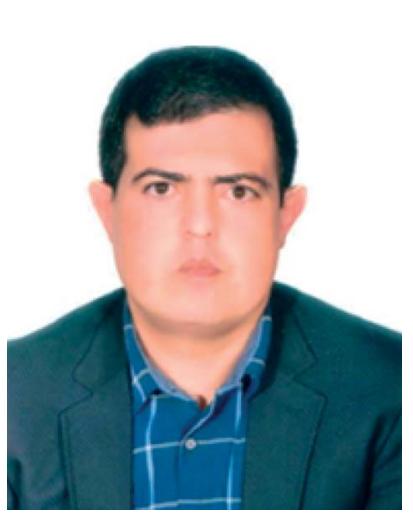

Mehdi Khalaj Associate Professor Dr Mehdi Khalaj was born in Karaj, Iran in 21/03/1982. He received his $P h D$ in 2014 in Inorganic chemistry under the supervision of Professor Sadegh Salehzadeh in Bu-Ali Sina University in Hamedan one of the oldest cities in the world. In 2019 he was awarded a best researchers prize in Qazvin province. He was an Assistant Professor in Islamic Azad University of Buinzahra Branch from 2014 and now has become to Associate Professor in that University. His research interests include organic and inorganic synthesis, porous coordination polymers based on phosphonates, synthesis, complexation and structural studies of some diimine ligands, nanocomposite green chemistry and so on. by Leffler and Hathaway in 1948. The reaction mixture of lawsone (2), amine and 37\% formalin (3) in absolute ethanol was allowed to stir at room temperature for one hour was warmed on the steam-bath for an additional hour, and was then left at room temperature overnight gave the corresponding aminonaphthoquinone 1 in $66-98 \%$ yields. In this study diethylamine failed to react, on the other hand, primary amines, such as butylamine, gave especially good yields (Scheme 1). ${ }^{32}$

However, two mechanisms may be operating in the formation of the aminomethylnaphthoquinone derivatives (4), depending on the reaction conditions: the first mechanism is preformation of the imine via the reaction of amine and aldehyde followed by nucleophilic attack of lawsone (2) to the activated imine or iminium species, and/or the second mechanism is Knovenagel-type condensation of lawsone with aldehyde followed by Michael-type 1,4-addition of amine to the alpha, betaconjugated carbonyl species formed. Apparently, mechanism (1) operates mostly in catalyzed transformations while mechanism (2) will probably be the one operating for uncatalyzed transformations (Scheme 2).

In 1949, Dalgliesh demonstrated that Mannich bases 5 were prepared by the reaction of lawsone, aldehydes and primary aliphatic amines or 2-aminopyridine in $\mathrm{EtOH}$ at room temperature for 3-24 h. The mechanism of the Mannich reaction is still obscure, it being uncertain whether the primary reaction is that of formaldehyde with the amine or with the active hydrogen component (Scheme 3). ${ }^{33}$ It has been suggested that the formation of aminonaphthoquinine 5 was occurred through the second mechanism as shown in Scheme 2.

Hydroxynaphthoquinones $\mathbf{1}$ and $\mathbf{6 a}-\mathbf{d}^{\mathbf{2 4}}$ were synthesized as previously described methods (Fig. 1). ${ }^{32,34}$ They have been submitted to molluscicidal bioassays against the snail Biomphalaria glabrata, intermediate host of Schistosoma mansoni. Several of the quinones $\mathbf{1}$ and $\mathbf{6 a - d}$ assayed showed significant molluscicidal activities, and correlation of their activities and electrochemical parameters showed that the first wave reduction potential is an important parameter. The easily reduced quinones $\left(>E_{\mathrm{p} 1 \mathrm{c}}\right)$ were more active against adult snails and against their egg masses, whilst the 3-methylamino-2-hydroxy derivatives presented higher negative reduction potentials and were not active as molluscicides.

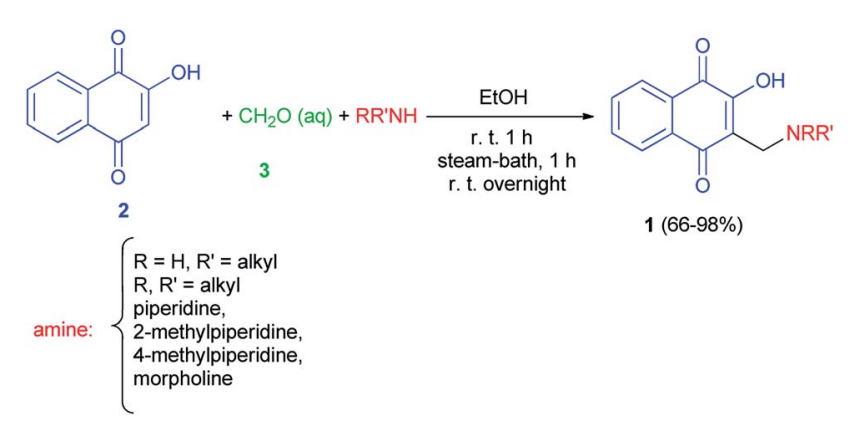

Scheme 1 Synthesis of 2-hydroxy-3-aminomethyl-1,4-naphthoquinones 1 . 


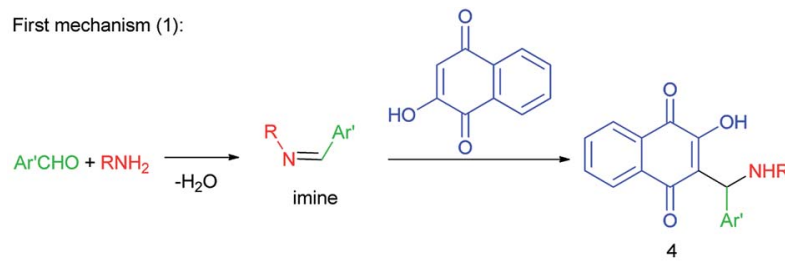

Second mechanism (2):

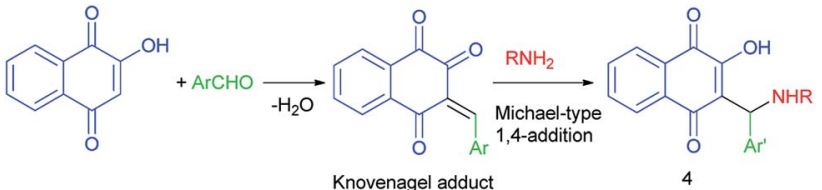

Scheme 2 Proposed mechanisms for the synthesis of aminomethylnaphthoquinones 4 .

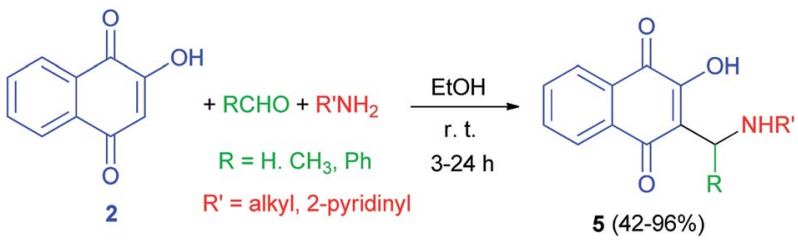

Scheme 3 Synthesis of aminonaphthoquinines 5 .

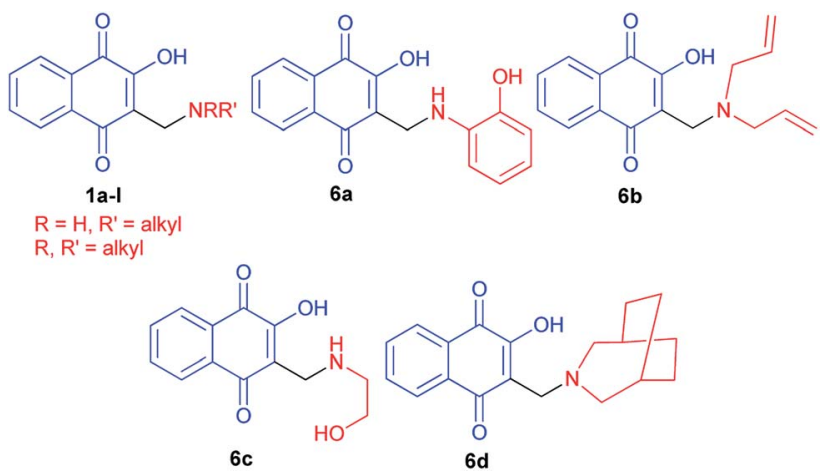

Fig. 1 Structures of the synthesized hydroxynaphthoquinones 1 and $6 a-d$

Aminomethylnaphthoquinones 7 were synthesized from the Mannich reaction of lawsone (2) with the desired substituted benzaldehydes and primary amines in ethanol as described previously, ${ }^{32,33}$ with some modifications (Scheme 4). ${ }^{25}$ Although AMNQs 7a-c exhibited similar antiviral activities against BoHV5 , AMNQ 7c was at least 50-fold less cytotoxic than the other two compounds. $^{3}$

2-Hydroxy-3-substituted-aminomethyl naphthoquinones 8ae, ${ }^{35}$ Mannich adducts, were obtained in high quantities by the classic reaction of lawsone (2), using amine and formaldehyde in alcoholic solution (Scheme 5), as previously reported by the Pinto group, ${ }^{24,36,37}$ based on the procedure described by Leffler and Hathaway. ${ }^{32}$ Compounds 8 exhibit molluscicidal activity $^{24,36,37}$ against the snail Biomphalaria glabrata, the
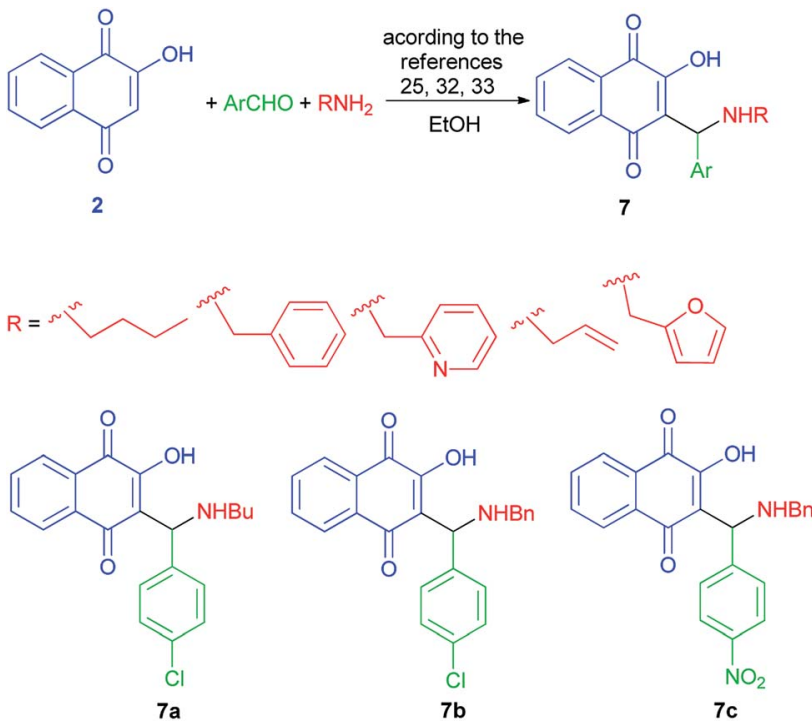

Scheme 4 Synthesis of aminomethylnaphthoquinone derivatives 7.

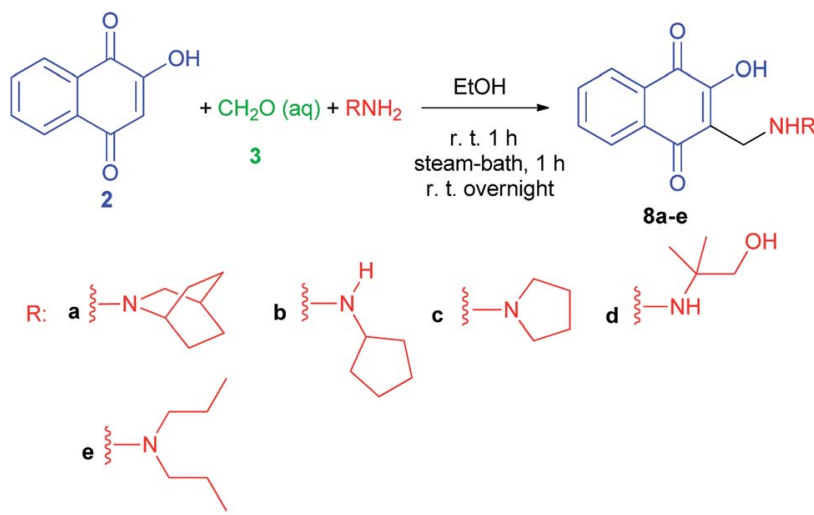

Scheme 5 Naphthoquinones 8 obtained by Mannich reaction from lawsone.

causative agent of schistosomiasis. Compound $\mathbf{8 e}$, the most active member of this group, was two times less effective than benznidazole $\left(\mathrm{IC}_{50} / 24 \mathrm{~h}=103.6 \pm 0.6 \mu \mathrm{M}\right)$, the standard anti- $T$. cruzi drug, and 2.6 times more active than crystal violet $\left(\mathrm{IC}_{50} /\right.$ $24 \mathrm{~h}=536.0 \pm 3.0 \mu \mathrm{M})$, which is recommended by WHO to hemotherapeutic centers in endemic areas for eliminating the parasite in blood used for transfusions. ${ }^{35}$

Krettli et al. noted that the naphthoquinones derived from lawsone (compounds 8a and 8e) showed the highest activity against $P$. falciparum chloroquine-resistant blood-stage parasites (clone W2), indicated by their low inhibitory concentration for $50 \%\left(\mathrm{IC}_{50}\right)$ of parasite growth. The therapeutic potential of the compounds was evaluated according to the selectivity index, which is a ratio of the cytotoxicity minimum lethal dose which eliminates $50 \%$ of cells and the in vitro $\mathrm{IC}_{50}$. Naphthoquinones $\mathbf{8 a}$ and $\mathbf{8 e}$, with activities similar to the reference antimalarial chloroquine, were also active against malaria in mice and suppressed parasitaemia by more than $60 \%$ in contrast to Norlapachol (9) which was inactive (Fig. 2). ${ }^{38}$ 

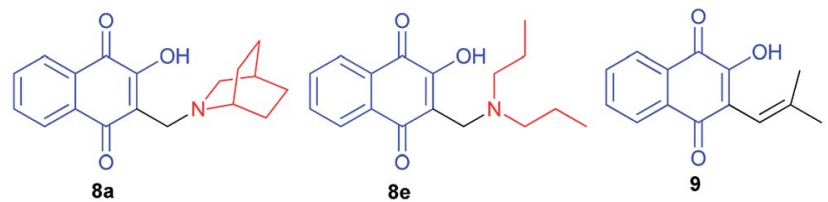

Fig. 2 Structure of the naphthoquinones derived from lawsone $(8 a, e$ and 9).

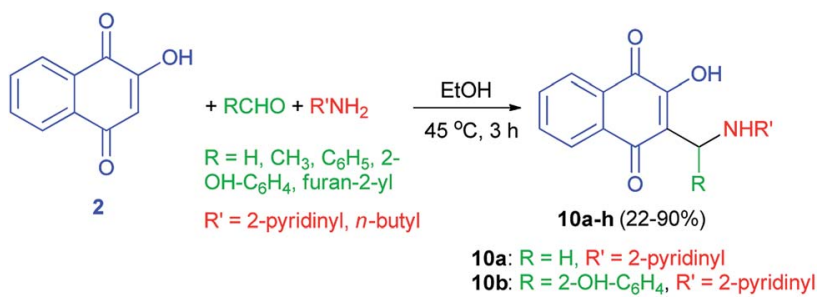

Scheme 6 Synthesis of 2-hydroxy-1,4-naphthoquinones 10.

A series of substituted derivatives of 2-hydroxy-1,4naphthoquinones $\mathbf{1 0}$ were prepared by a Mannich reaction from lawsone (2), aryl/alkyl aldehydes and 2-aminopyridine $/ n$ butylamine in EtOH at $45{ }^{\circ} \mathrm{C}$ for $3 \mathrm{~h}$ in $22-90 \%$ yields (Scheme 6). Minimum inhibitory concentration (MIC) of the synthesized compounds was measured against Mycobacterium tuberculosis (MTB) H37Ra strain. Among them, two compounds 10a,b showed antibacterial activity within the MIC range of 20-50 $\mu \mathrm{g}$ $\mathrm{mL}^{-1}$ while the other compounds did not show antibacterial activity. It was found that compound 10a showed the high activity anti-tuberculosis among other compounds, although cytotoxicity issues have been observed when evaluated on Verocells for further concerns. ${ }^{39}$

The synthesis of two new PPI-G1 dendrimers containing lowsone $\mathbf{1 1}$ as pharmacophoer is reported by Ndiaye and coworkers. The compounds were synthesized in course of Mannich reaction involving lawsone (2), the commercial PPIG1(polypropyleneimine-G1) dendrimer with functional amino groups on the exterior and acetaldehyde or benzaldehyde in

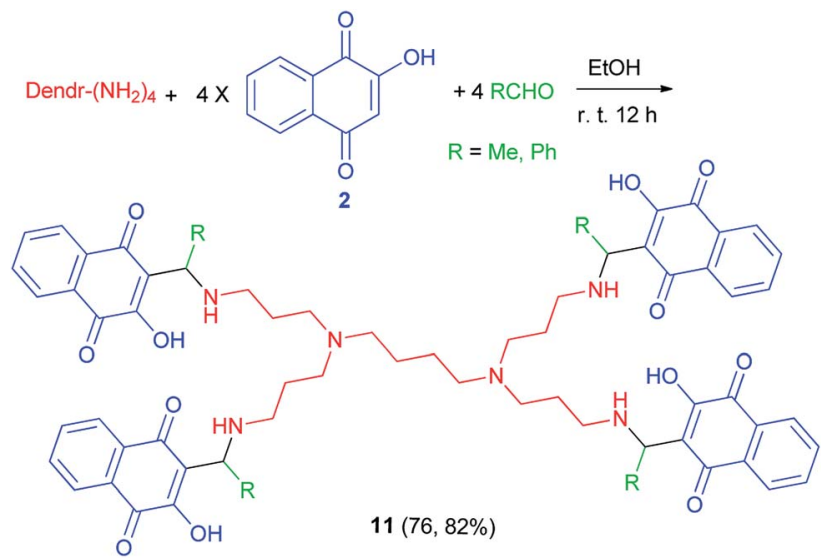

Scheme 7 Synthesis of PPI-G1 dendrimers containing lowsone 11.

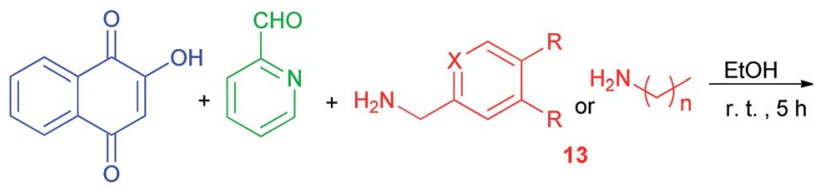

2

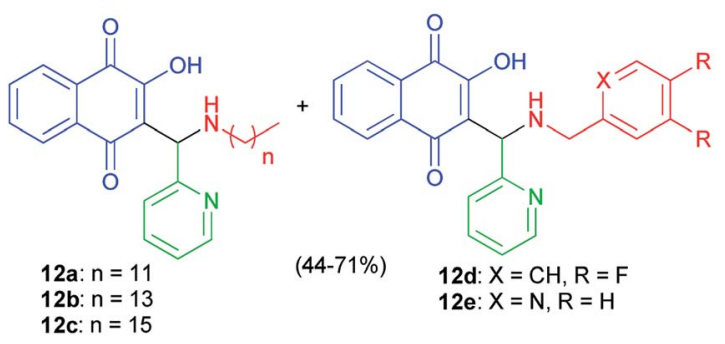

Scheme 8 Synthesis of Mannich bases 12a-e.

$4: 1: 4$ molar ratio in absolute EtOH at room temperature for overnight in the dark (Scheme 7). The reaction mechanism could be explained briefly in a few words, i.e. condensation of the amino with the acidified aldehyde to give the imine followed by protonation and addition of lawsonate anion (mechanism $(1))^{40}$

The Mannich bases 12a-e were prepared in $44-71 \%$ yields via Mannich reaction of lawsone, 2-pyridylcarboxaldehyde and the corresponding amines 13 in detail, dodecyl amine, tetradecyl amine, hexadecyl amine, 3,4-difluorobenzylamine and 2pyridylmethylamine in EtOH at room temperature for $5 \mathrm{~h}$ (Scheme 8). In addition, closely related vanillyl and 3,4difluorophenyl derivatives 14a-e and 15a-e were prepared. Analogously to the synthesis of compounds 12a-e, the Mannich reaction of lawsone with vanillins and the corresponding primary amines in EtOH gave the Mannich bases 14a-e as orange-red solids. In addition, reaction of lawsone with 3,4difluorobenzaldehyde and various primary amines led to<smiles>[R]c1ccc(C=O)cc1[Z17]=C1C=C(O)C(=O)c2ccccc2C1=O</smiles>

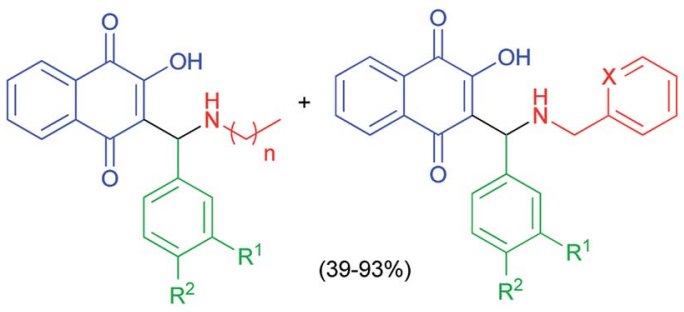

14a: $n=6, R^{1}=O M e, R^{2}=O H$ 14b: $n=11, R^{1}=O M e, R^{2}=O H$ 14c: $n=15, R^{1}=O M e, R^{2}=O H$ 14d: $X=C H, R^{1}=O M e, R^{2}=O H$ 14e: $X=N, R^{1}=O M e, R^{2}=O H$

Scheme 9 Synthesis of Mannich bases 14 and 15. 
<smiles>[R]NC([R])C1=C(O)C(=O)c2ccc([R16]([H])([H])[H])cc2C1=O</smiles>

Scheme 10 Synthesis of 3-(aminomethyl)naphthoquinones 16.

compounds 15a-e (orange-red solids). These target compounds were obtained in $\mathrm{EtOH}$ at room temperature in moderate to high yields (39-93\%) (Scheme 9). Substituted lawsone Mannich bases 12a-e, 14a-e and 15a-e tested for their biological activities. The new fatty alkyl substituted compounds 12a-c exhibited strong and selective growth inhibitory activities in the low onedigit micromolar and sub-micromolar range against a panel of human cancer cell lines associated with ROS formation. In addition, compounds 12a-c revealed sub-micromolar antitrypanosomal activities against parasitic Trypanosoma brucei cells via deformation of the microtubule cytoskeleton. The $\mathrm{N}$ hexadecyl compound 12c was also highly active against locally isolated Entamoeba histolytica parasite samples exceeding the activity of metronidazole. ${ }^{30}$

The synthesis of 3-(aminomethyl)-2-hydroxy-1,4naphthoquinones 16 was carried out following a procedure described previously. ${ }^{25}$ The products were isolated as
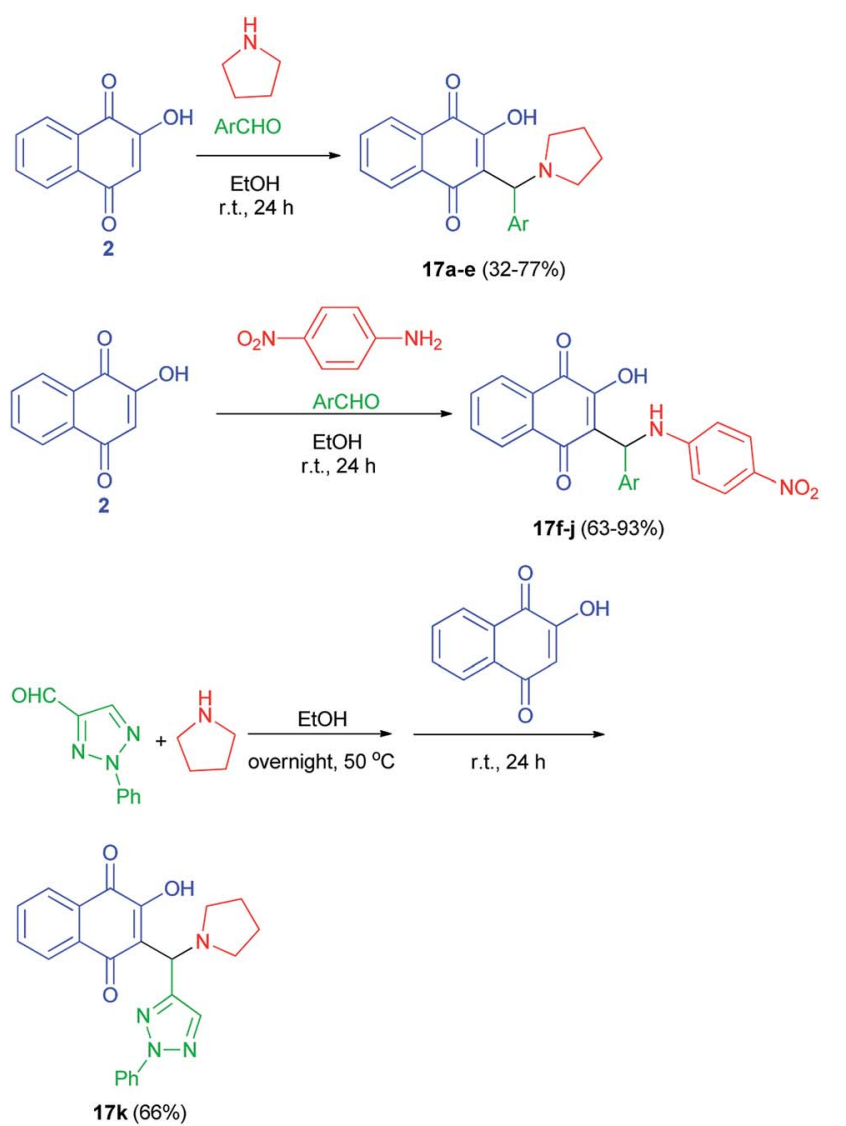

Scheme 11 Synthesis of aminonaphthoquinone Mannich bases 17. analytically pure orange powders with yields ranging from 3394\% (Scheme 10). In general, the compounds 16 have shown high to moderate activity against the HL-60 (promyelocytic leukaemia) cell line with $\mathrm{IC}_{50}=1.1-19.2 \mu \mathrm{M}$. The results suggest that the nature of the aryl moiety introduced in the structure of products by the aldehyde component is crucial to the cytotoxicity, and although the group originated from the primary amine has a lesser influence, aromatic ones were found to suppress the activity. ${ }^{41}$

Greco et al. succeeded in preparation of aminonaphthoquinone derivatives $\mathbf{1 7}$ from lawsone (2), aldehydes and amines in $\mathrm{EtOH}$ at room temperature in the dark for $24 \mathrm{~h}$. Also, for the synthesis of the lawsone derivative $17 \mathbf{k}$, a mixture of 2 phenyl-2H-1,2,3-triazole-4-carbaldehyde and pyrrolidine in ethanol was stirred overnight at $50{ }^{\circ} \mathrm{C}$. After this time, lawsone was added and the mixture was allowed to react for $24 \mathrm{~h}$ in the dark (Scheme 11). Among the synthetic lawsone derivatives, 2hydroxy-3-((2-hydroxyphenyl)(pyrrolidin-1-yl)methyl)

naphthalene-1,4-dione, 2-hydroxy-3-(((4-nitrophenyl) amino)(phenyl)methyl)naphthalene-1,4-dione and 2-hydroxy-3((2-hydroxyphenyl)((4-nitrophenyl)amino)methyl)naphthalene1,4-dione showed high activity against Candida albicans ATCC 10231, with minimal inhibitory concentrations (MICs) and minimal fungicidal concentrations (MFCs) ranging from 20 to 330 and from 80 to $330 \mu \mathrm{g} \mathrm{mL} \mathrm{m}^{-1}$, respectively. Moreover, they also showed a mechanism of action on exogenous ergosterol. ${ }^{29}$

Biersack et al. have been prepared a series of new lawsone Mannich bases 18 in $30-64 \%$ yields from lawsone (2), salicylaldehydes or nitrofurfural and dodecylamine or hexadecylamine or 2-aminomethylpyridine in $\mathrm{EtOH}$ at room temperature for 30-60 min. Compounds 18 were converted to the hydrochloride salts 19 by reaction with acetyl chloride in ethyl alcohol at $50{ }^{\circ} \mathrm{C}$ for $1 \mathrm{~h}$ (Scheme 12). These compounds tested for activities against Leishmania major, Toxoplasma gondii, and Trypanosoma brucei parasites. The hydrochloride salts 19 of the Mannich bases 18, derived from unsubstituted salicylaldehyde and long chained alkyl amines, were selectively and strongly active against $T$. gondii cells and appear to be new promising drug candidates against this parasite. Also, Some of them
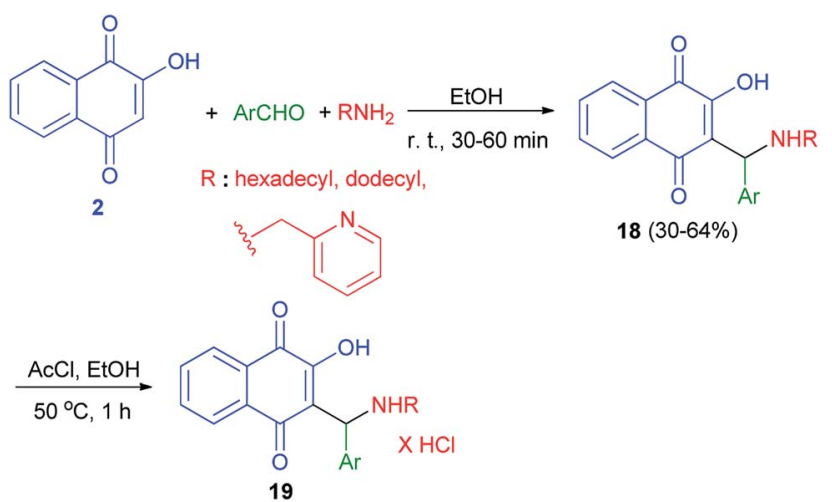

Scheme 12 Synthesis of lawsone Mannich bases 18 and their hydrochloride salts 19 . 
<smiles>[R1]c1cccc(C=O)c1</smiles><smiles>[R]NC(C1=C(O)C(=O)c2ccc([14CH3])cc2C1=O)c1[R1]cccc1</smiles>

$20(54-85 \%)$

Scheme 13 Synthesis of aminonaphthoquinone derivatives 20 .

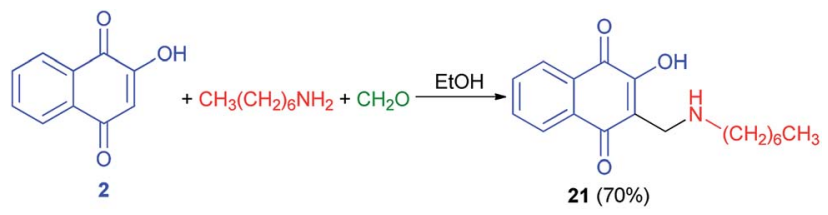

Scheme 14 Synthesis of 3-(N-(1-heptyl)aminomethyl)-2-hydroxynaphtoquinone 21 .

proved active against $L$. major promastigotes and up to four times more efficacious against $L$. major amastigotes. ${ }^{42}$

Thakore et al. described synthesis of Mannich bases of lawsone 20 by the reaction of lawsone, aromatic aldehydes and aliphatic amines in EtOH at room temperature for 2-14 h in 54$85 \%$ yields. It primarily forms the iminium ion by condensation of amine and aldehyde. Subsequently, the nucleophile lawsonate attacks iminium ion (analogous to the enolate) to give a Mannich base 20. Overall, the compounds with aliphatic substituent at $\mathrm{R}$ position and hydroxyl substituted phenyl ring at $\mathrm{R}^{1}$ position are associated with the highest activities. The effective $\mathrm{IC}_{50}$ concentration for compounds are 1.68-4.64 $\mu \mathrm{M}$. These compounds showed higher anticancer potential against HepG2 cells (Scheme 13). ${ }^{43}$

Moreover, compound $\mathbf{2 1}$ was obtained in $70 \%$ yield using a direct condensation of $n$-heptylamine on 2-hydroxynaphthoquinone (2) in the presence of formaldehyde in $\mathrm{EtOH}$ (Scheme 14). This novel atovaquone derivative 21 was tested for their in vitro activity against two apicomplexan parasites of medical importance, Toxoplasma gondii and Plasmodium falciparum, including resistant strains to atovaquone ( $T$. gondii) and chloroquine (P. falciparum). ${ }^{\mathbf{4}}$

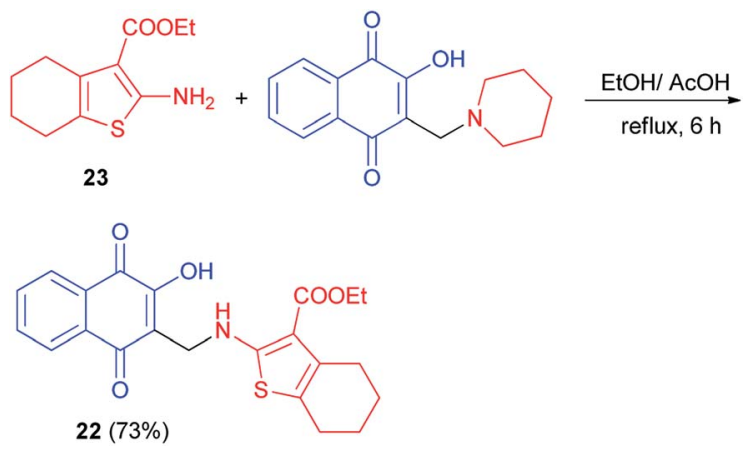

Scheme 15 Synthesis of aminonaphthoquinone 22.

\subsection{Acid catalyzed reactions}

Synthesis of aminonaphthoquinone 22 in $73 \%$ yield has been carried out by the reaction of ethyl 2 -amino-4,5,6,7- tetrahydrobenzo[b]thiophene-3-carboxylate 23 with 2-hydroxy-3((piperidin-1-yl)methyl)naphthalene-1,4-dione in a mixture ethanol/acetic acid under reflux for $6 \mathrm{~h}$ (Scheme 15). It was screened for antioxidant activity. Calculation of the inhibition ratio (\%) showed clearly that compound 22 exhibited moderate activity $(63.17 \%)$ compared with ascorbic acid $(89.87 \%)$ as a standard antioxidant. Also, it was selected for bleomycindependent DNA-damage testing. If the sample to be tested is able to reduce the bleomycin- $\mathrm{Fe}^{3+}$ to bleomycin- $\mathrm{Fe}^{2+}$, DNA degradation in this system will be stimulated, resulting in a positive test for pro-oxidant activity. The results showed that compound 22 has an ability to protect DNA from the induced damage by bleomycin. Thus, it would appear generally that introducing of naphthoquinone moiety enhances the antioxidant properties of 2-aminothiophene compounds. ${ }^{45}$

Greco et al. demonstrated that one-pot protocol was developed for the synthesis of a series of new aminonaphthoquinones 24 in 55-98\% yields from 2-hydroxy-1,4naphthoquinone (2), aldehydes and 4-nitroaniline or pyrolidine by three-component Mannich reaction using catalytic amount of $p$-TsOH in $\mathrm{CH}_{3} \mathrm{CN}$ at room temperature for $0.5-48 \mathrm{~h}$. A reasonable mechanism possibility is shown in Scheme 16. First, the catalyst protonates the carbonyl oxygen of the aldehyde favoring the formation of the iminium ion which reacts
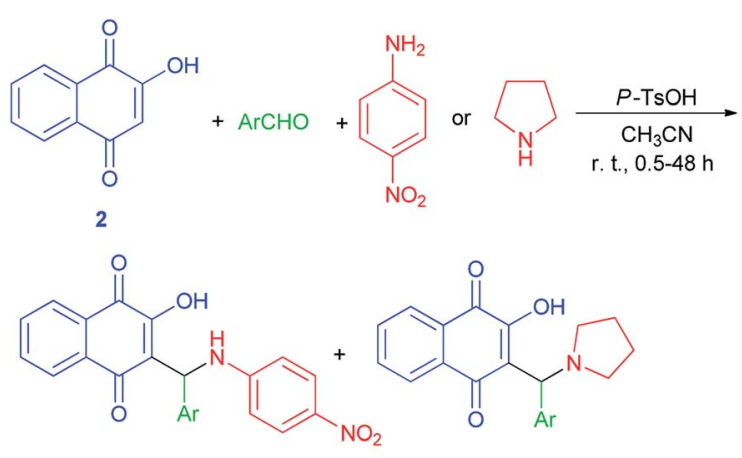

$24(55-98 \%)$

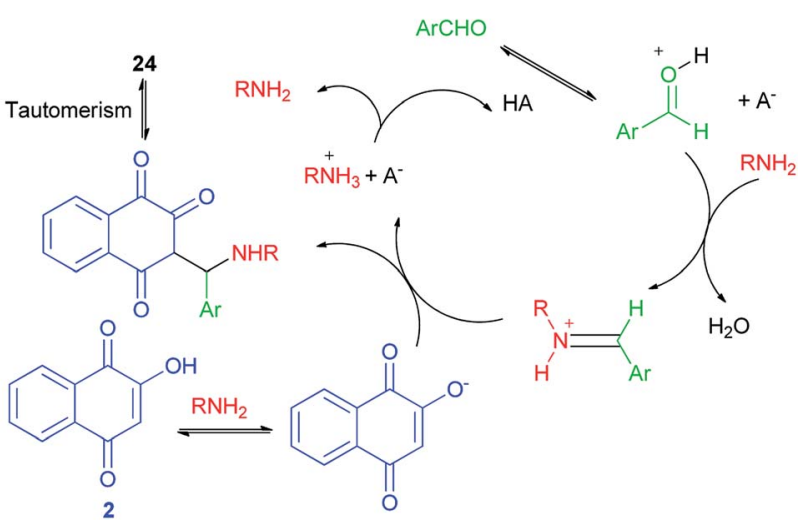

Scheme $16 p-\mathrm{TsOH}$ catalyzed synthesis of aminonaphthoquinones 24. 


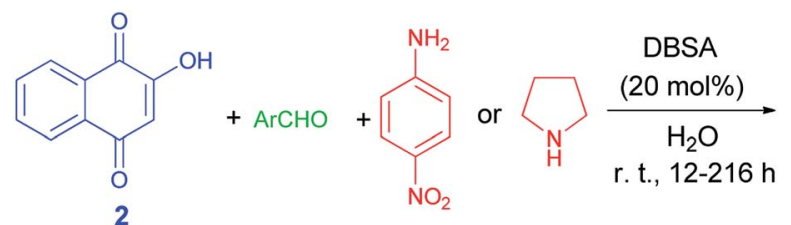<smiles>O=C1C(O)=C(C(Br)Nc2ccc([N+](=O)[O-])cc2)C(=O)c2ccccc21</smiles>

$25(21-85 \%)$

Scheme 17 DBSA catalyzed synthesis of aminonaphthoquinones 25.

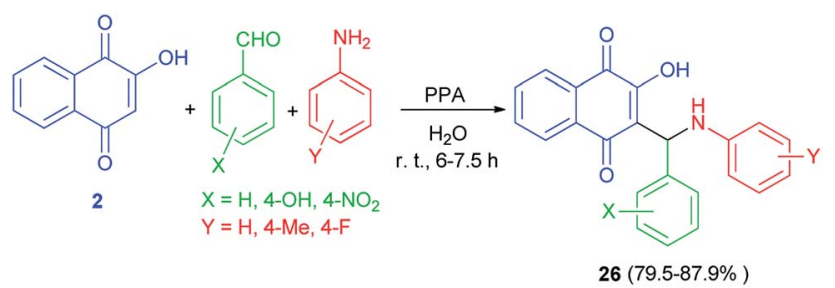

Scheme 18 PPA catalyzed synthesis of hydroxylnaphthalene-1,4dione derivatives 26 .

with the nucleophilic species, that may be the ion formed from deprotonation of lawsone by the amine. Finally, the product is obtained after tautomerism and the catalyst is regenerated. ${ }^{\mathbf{4 6}}$ Environmentally friendly one-pot protocol was developed for the first synthesis of aminonaphthoquinones 25 in $21-85 \%$ yields derived from lawsone (2) via a multi-component Mannich reaction in aqueous media using a catalytic amount of dodecyl benzenesulfonic acid (DBSA) (20 mol\%), exploring a Brønsted acid-surfactant catalyst (BASC) concept, at room temperature for 12-216 h. Most likely, all of the reaction steps, from the iminium salt formation to the final Mannich adduct, occur inside of the surfactant micelles due to the affinity of the medium for reactants/intermediates (Scheme 17). In this context, DBSA enhances the chemical yield and decreases the reaction time by building a colloidal dispersion system and protonating electrophilic species, the aldehyde and imine, increasing its reactivity towards the nucleophile at the same time. ${ }^{47}$

An efficient one-pot synthesis of lawsone derivatives 26 in 79.5-87.9\% yields is accomplished by a three-component reaction of 2-hydroxynaphthalene-1,4-dione (2), aromatic aldehydes and amines carrying electron-donating or electron-withdrawing substituents in water under ambient temperature catalyzed by phenylphosphinic acid for 6-7.5 h (Scheme 18). It should be noted that aliphatic aldehyde reacted poorly under the same conditions. The proposed mechanism for the formation of the compounds 26 is shown in Scheme 2 (mechanism (1)). ${ }^{48}$

A series of Mannich bases of lawsone as 3-alkyl/aryl/ heteroaryl substituted aminonaphthoquinones 27 were synthesized in 56.6-82.5\% yields from lawsone (2), amines and

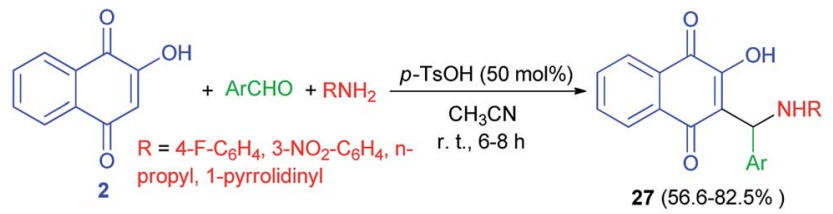<smiles>O=C1C(O)=C(C(Nc2ccc(F)cc2)c2ccccc2)C(=O)c2ccccc21</smiles><smiles>[X]c1cccc(C(Nc2cccc([N+](=O)[O-])c2)C2=C(O)C(=O)c3ccccc3C2=O)c1</smiles>

$27 a$

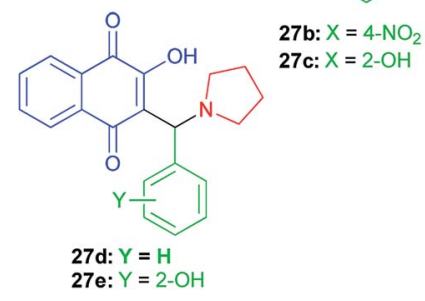

Scheme $19 p$-TsOH catalyzed Mannich bases of lawsone 27.

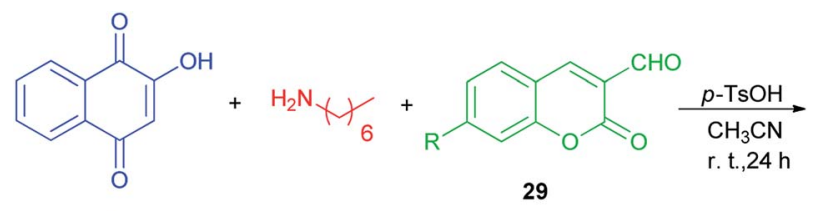

2

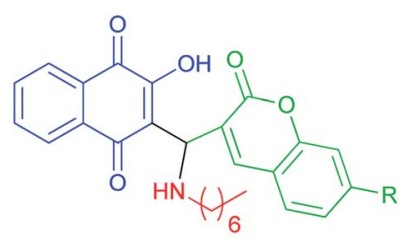

28a: $R=H(51 \%)$

28b: $R=$ OMe $(58 \%)$

Scheme 20 Synthesis of Mannich bases 28a-b.

aromatic aldehydes in $\mathrm{CH}_{3} \mathrm{CN}$ at room temperature in presence of $p$-TsOH (50 mol\%) for 6-8 h (Scheme 19). Among synthesized compounds, five compounds (27a-e) showed good antimalarial activity against both chloroquine (CQ)-sensitive (3D-7) and -resistant (RKL-2) strains of $P$. falciparum, which, however, was considerably less than that of the standard reference drug, CQ. The antimalarial activity of these five compounds was found better against sensitive $\left(\mathrm{IC}_{50}=0.411-0.502 \mu \mathrm{g} \mathrm{mL}^{-1}\right)$ strain than the resistant $\left(\mathrm{IC}_{50}=1.391-2.394 \mu \mathrm{g} \mathrm{mL}{ }^{-1}\right)$ one. ${ }^{23}$

Mannich bases 28a-b derived from lawsone, heptylamine and 3-formylcoumarins (29) have been synthesized in the presence of $p$ - $\mathrm{TsOH}\left(20 \mathrm{~mol} \%\right.$ ) in $\mathrm{CH}_{3} \mathrm{CN}$ at room temperature for $24 \mathrm{~h}$ in the dark in 51 and 58\% yields, respectively (Scheme $20)$. The cyclic voltammetry data of these compounds showed a charge transfer (CT) process from the coumaryl to the naphthoquinonoid group, in spite of the absence of conjugation between these two fragments, with the nitrogen atom playing an important role. ${ }^{49}$ 
<smiles>O=C1C=C(O)C(=O)c2ccccc21</smiles>

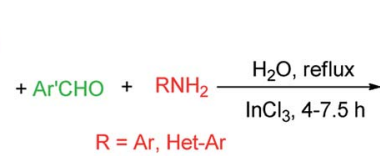<smiles>[R]NC(Br)C1=C(O)C(=O)c2ccccc2C1=O</smiles>

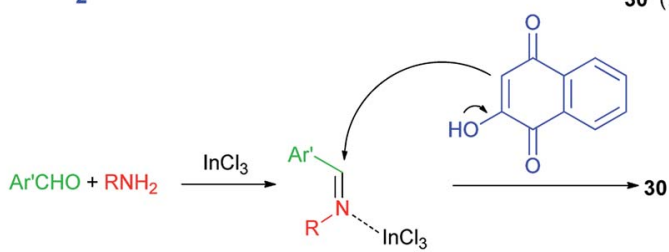

Scheme $21 \quad \mathrm{InCl}_{3}$ catalyzed synthesis of aminonaphthoquinones 30

\subsection{Metal catalyzed reactions}

An efficient one-pot synthesis of fluorescent hydroxyl naphthalene-1,4-dione derivatives 30 in 78-91\% yields by atomeconomical and three-component reaction of 2hydroxynaphthalene-1,4-dione (2), aromatic aldehydes and heterocyclic or carbocyclic amines in the presence of a catalytic amount of $\mathrm{InCl}_{3}$ in refluxing water for $4-7.5 \mathrm{~h}$ is reported. The products were fluorescent in methanol solution emitting at green light (546-560 $\mathrm{nm})$. Possible mechanism for the formation of products 30 as shown in Scheme 21. ${ }^{31}$

Ghodsi et $a .^{50}$ have published synthesis of 2-arylaminonaphthoquinone derivatives 31a-c from lawson (2), 4-hydroxybenzaldehyde and aryl amines in the presence of $\mathrm{InCl}_{3}$ in refluxing EtOH according to the previously reported procedure (Scheme 22). ${ }^{31}$

Aminonaphthoquinone derivatives 32 have been prepared in $88-93 \%$ yields by one-pot three-component condensation

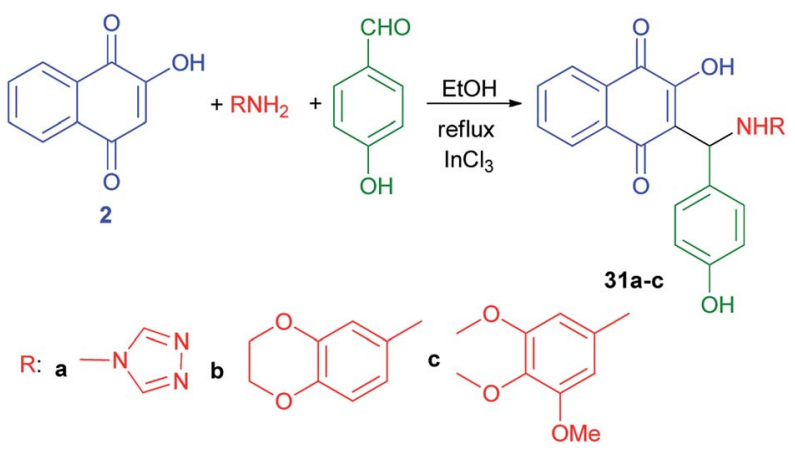

Scheme $22 \mathrm{InCl}_{3}$ Catalyzed synthesis of 2-arylaminonaphthoquinones $31 \mathrm{a}-\mathrm{c}$.

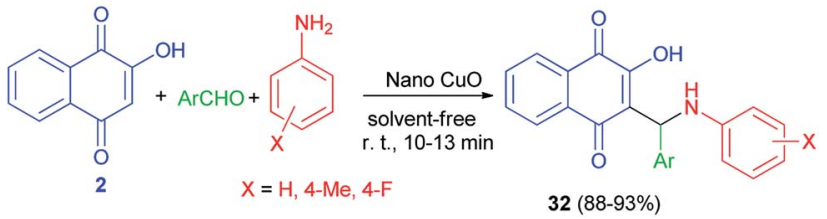

Scheme 23 Nano CuO catalyzed synthesis of aminonaphthoquinone derivatives 32 .

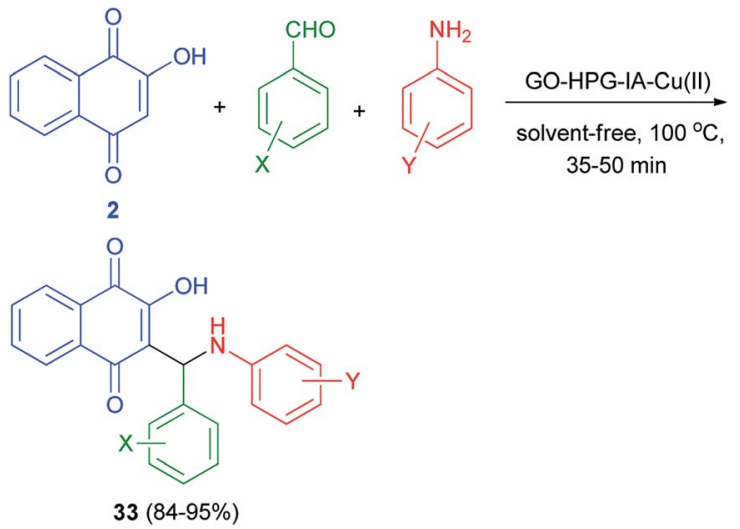

Scheme 24 Synthesis of aminonaphthoquinone derivatives 33 using $\mathrm{Cu}(I)$ immobilized on graphene oxide.

reaction of aromatic aldehydes, aromatic amines, and 2hydroxynaphthalene-1,4-dione (2) in the presence of nano-copper(II) oxide (8 mol\%) as catalyst under mild, ambient and solvent-free conditions for 10-13 $\mathrm{min}$. The proposed catalytic mechanism for the preparation of $\mathbf{3 2}$ using nano-copper(II) oxide as the catalyst is described in Scheme $23 .^{51}$ The proposed mechanism is similar to the first mechanism as shown in Scheme 2.

$\mathrm{Cu}$ (II) immobilized on hyperbranched polyglycerol (HPG) functionalized graphene oxide catalyzed synthesis of aminonaphthoquinones 33 in $84-95 \%$ yields via one-pot threecomponent condensation reaction of lawsone (2), benzaldehyde and aniline derivatives at $100{ }^{\circ} \mathrm{C}$ for $35-50$ min under solvent-free conditions (Scheme 24). According to the plausible mechanism, firstly, the aldehyde is activated by the GO-HPGIA- $\mathrm{Cu}$ (II) catalyst which upon nucleophilic attack of amine to form imine. Subsequently, lawsone attacks to imine in the presence of the GO-HPG-IA-Cu(II) catalyst and undergoes tautomeric proton shift to generate the aminonaphthoquinone derivative $\mathbf{3 3}$ and releases the catalyst for the next run. ${ }^{52}$

Synthesis of mono-aminonaphthoquinone derivatives $\mathbf{3 4}$ catalyzed by $\mathrm{Bi}(\mathrm{III})$ immobilized triazine dendrimer-stabilized magnetic nanoparticle $\mathrm{Fe}_{3} \mathrm{O}_{4} @ \mathrm{ODSN}-\mathrm{Bi}(\mathrm{III})(3 \mathrm{~mol} \%$ ) via a one-pot three-component reaction of lawsone, aldehydes containing electron with-drawing or electron-donating groups and amines (anilines, 4-methylaminopyridines, $i$-butylamine, pyrolidine and piperidine) in EtOH as a green solvent at room temperature for $5-90 \mathrm{~min}$ in $\mathbf{7 0 - 9 8 \% ~ y i e l d s . ~ T h i s ~ c a t a l y t i c ~}$ system also showed excellent activity in the synthesis of symmetric and unsymmetric bis-aminonaphthoquinones 35-38 from dialdehyde (terephthaladehyde and isophthalaldehyde) and/or diamines (benzene-1,4-diamine and 1,2-ethylenediamine) in EtOH at room temperature for 15-45 min in high yields (85-98\%) and purity via an easy work-up procedure (Scheme 25). A plausible mechanism for the $\mathrm{Fe}_{3} \mathrm{O}_{4} @$ OTDSN$\mathrm{Bi}(\mathrm{III})$ catalyzed synthesis of aminonaphthoquinones is depicted in Scheme 26. First, the aldehyde is activated by the catalyst to give 39 which upon nucleophilic attack of amine forms imine 40. Then, 2-hydroxynaphthalene-1,4-dione attacks imine 40 in 


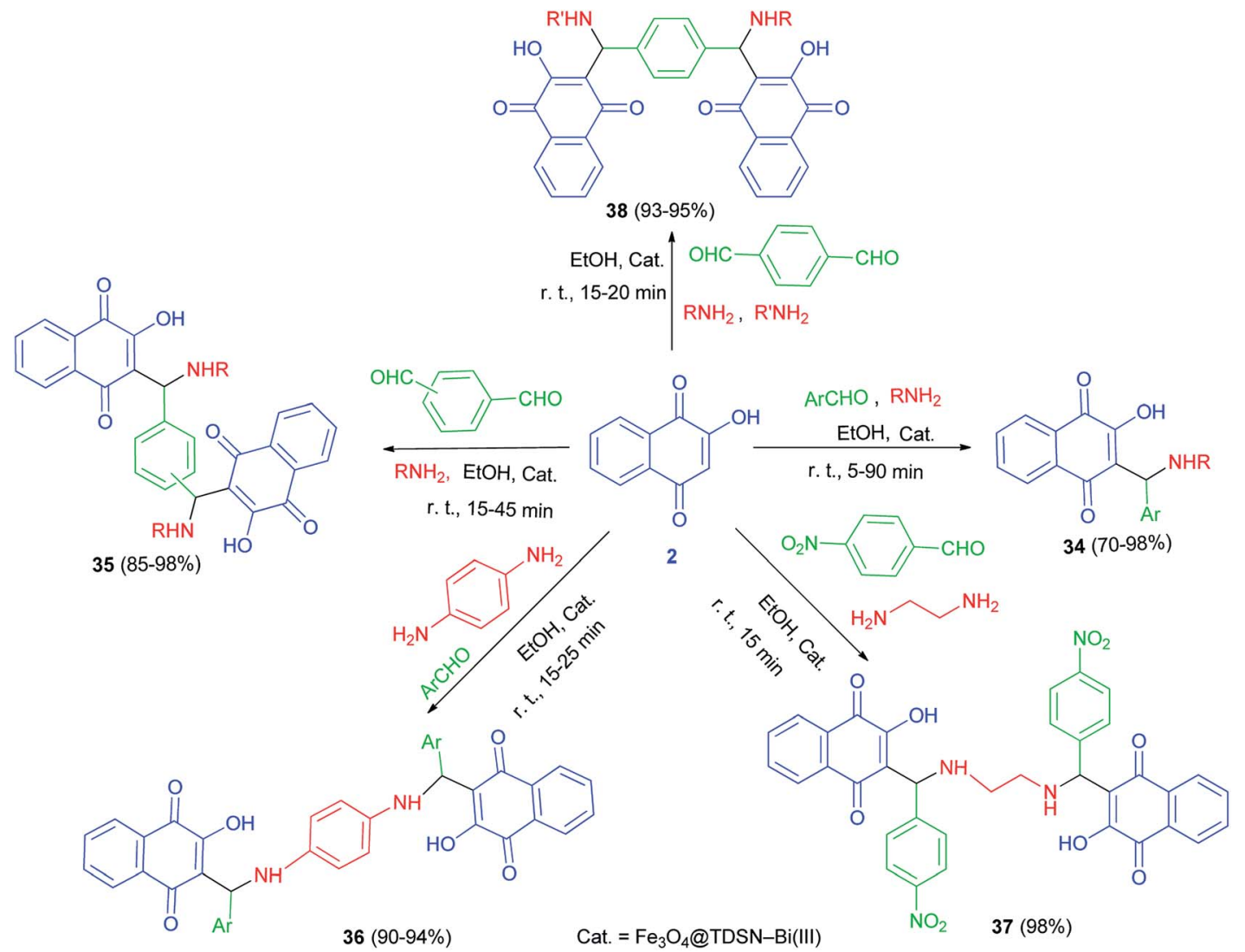

Scheme 25 Synthesis of mono-and bis-aminonaphthoquinone derivatives 34-38.

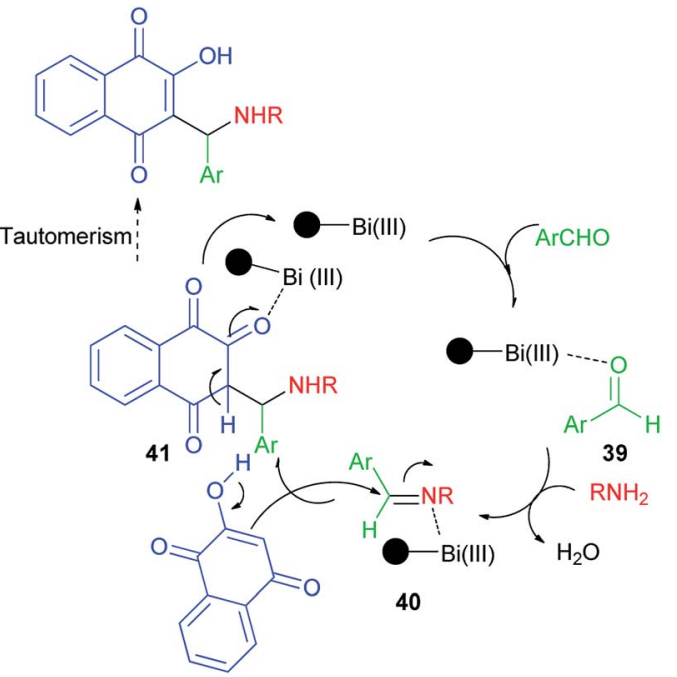

Scheme 26 Plausible mechanism for the $\mathrm{Fe}_{3} \mathrm{O}_{4}$ aTDSN-Bi(III) catalyzed synthesis of aminonaphthoquinones 34-38.

the presence of the catalyst to furnish intermediate $\mathbf{4 1}$ desired products and releases the catalyst for the next run. ${ }^{53}$

\subsection{Other-types of catalyzed reactions}

Enantioenriched naphthoquinone Mannich base $\mathbf{4 2}$ by organocatalyzed nucleophilic additions of 2-hydroxy-1,4- naphthoquinone (2) to in situ formed imines has been reported by Westermann and Ayaz. In this process, lawsone (2) to preformed imine 43 using Takemoto's catalyst 44 (10 mol\%) afforded the Mannich base $\mathbf{4 2}$ in only $\mathbf{4 0 \%}$ yield and a very low
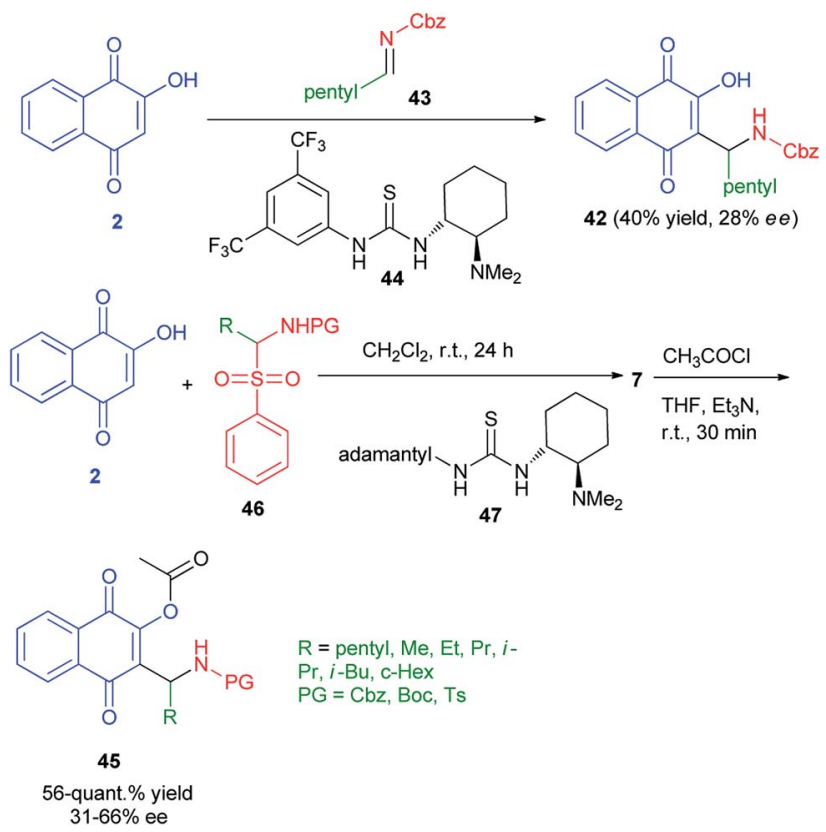

Scheme 27 Preparation of Mannich bases 42 and 45. 


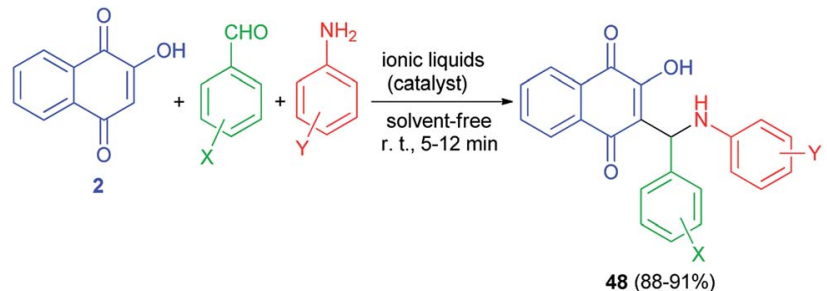

Scheme 28 lonic liquid catalyzed synthesis of aminonaphthoquinones 48 .

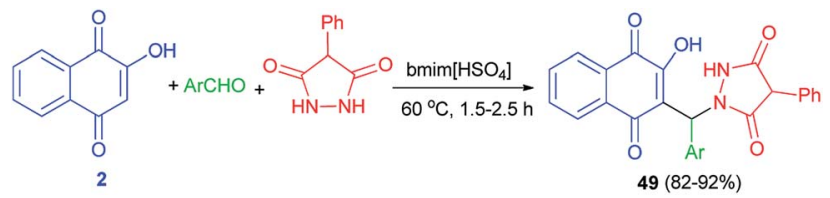

Scheme 29 Task-specific ionic liquid catalyzed synthesis of naphthoquinone-urazole hybrids 49 .

enantioselectivity of $28 \%$ ee. Also, enantioenriched naphthoquinone Mannich bases $\mathbf{4 5}$ have been synthesized by the reaction of 2 with $\alpha$-amidosulfone 46 in the presence of organocatalyst 47 in $\mathrm{CH}_{2} \mathrm{Cl}_{2}$ at room temperature for $24 \mathrm{~h}$. Then, the reaction of title product with acetyl chloride in the presence of $\mathrm{Et}_{3} \mathrm{~N}$ in $\mathrm{THF}$ at room temperature for $30 \mathrm{~min}$ gave the corresponding products 45 in 56-quant.\% yield and $31-66 \%$ ee (Scheme 27)..$^{54}$

Condensation of 2-hydroxynaphthalene-1,4-dione (2), anilines, and aromatic aldehydes in the presence of the mild basic ionic liquids, (A) DBU [ $\left.\mathrm{CH}_{3} \mathrm{COO}\right]$ (10 mol\%), (B) Pyrr [ $\left.\mathrm{CH}_{3} \mathrm{COO}\right]$ (15 mol\%), (C) Pyrr[HCOO] (15 mol\%), (D) Pip [ $\left.\mathrm{CH}_{3} \mathrm{COO}\right]$ (10 mol\%), (E) Pip[HCOO] (10 mol\%), (F) [Hmim] [HCOO] (15 mol\%) and (G) 3-HPAA (15 mol\%) as the most efficient catalysts with respect to the reaction time and yields under solvent-free and ambient conditions for 5-12 min afforded the corresponding aminonaphthoquinones 48 in high to excellent yields (Scheme 28). ${ }^{55}$ The proposed mechanism for the preparation of compounds $\mathbf{4 8}$ is similar to the first mechanism as indicated in Scheme 2.

Khurana et $a l .{ }^{56}$ described synthesis of naphthoquinoneurazole hybrids 49 in high yields (82-92\%) via one-pot condensation of lawsone (2), various aromatic aldehydes having electron with-drawing and electron-releasing groups and 4-phenylurazole using task specific ionic liquid (bmim[ $\left[\mathrm{HSO}_{4}\right]$ )
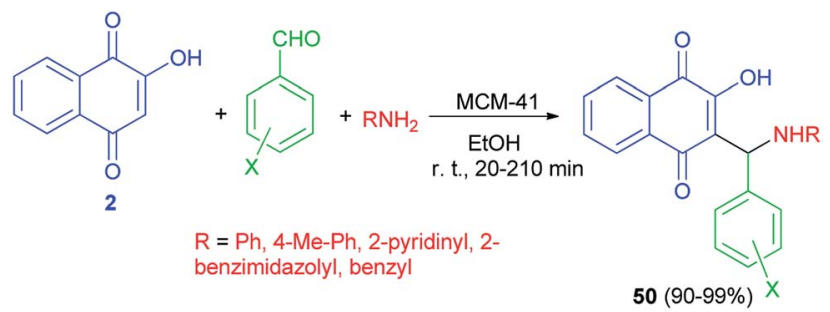

Scheme 30 MCM-41 catalyzed synthesis of aminomethylnaphthoquinones 50 .

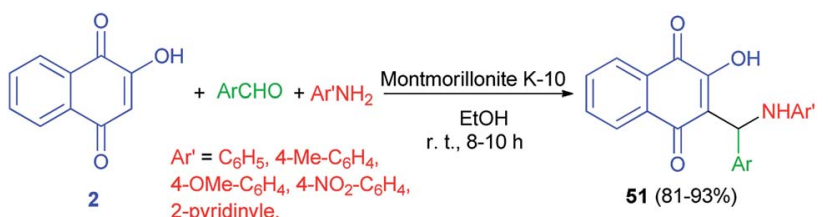

2-pyridinyle

2-benzimidazolyl

2-benzothiazolyl

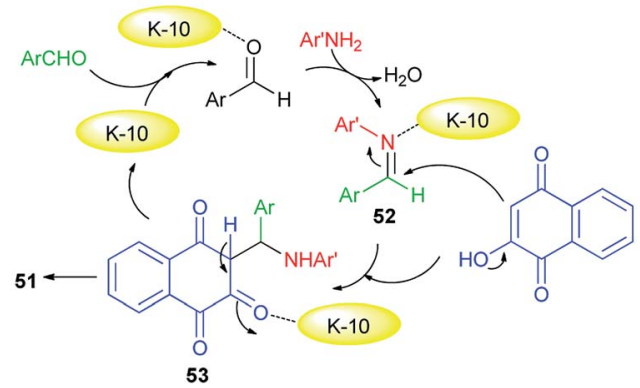

Scheme 31 Montmorillonite K-10 catalyzed synthesis of aminonaphthoquinones 51

(10 mol\%) at $60{ }^{\circ} \mathrm{C}$ for $1.5-2.5 \mathrm{~h}$ (Scheme 29). A mechanistic rationale portraying the probable sequence of steps is similar to the second mechanism as shown in Scheme 2. All newly synthesized compounds were screened for in vitro antioxidant and anticancer activities against human breast (T47D), colon (HCT-15), lung (NCI-H522), liver (HepG-2) and ovary (PA-1) cancer cell lines. The in vitro antioxidant and anticancer activity of these compounds revealed that all of the synthesized naphthoquinone-urazole hybrids $\mathbf{4 9}$ have a significant activity. 3-Bromophenyl, 2-methylphenyl, 2-naphthyl and 3-methylphenyl derivatives were more active among all the naphthoquinone-urazole hybrids.

Naimi-Jamal et al. succeeded in preparation of 2-hydroxy-1,4naphthoquinone derivatives $\mathbf{5 0}$ from 2-hydroxynaphthalene1,4-dione (2), aromatic aldehydes and heterocyclic or carbocyclic amines using MCM-41 nanoporous as catalyst in EtOH at room temperature for $20-210 \mathrm{~min}$. The aromatic aldehydes carrying both electron-withdrawing and electron-releasing substituents were converted to their corresponding products in high yields (90-99\%) (Scheme 30). ${ }^{57}$

An efficient one-pot protocol for the synthesis of 2((substituted amino)(4-phenyl)methyl)-3-hydroxy-naphthalene1,4-diones 51 has been developed by the three-component reaction of 2-hydroxynaphthalene-1,4-dione (2), aromatic

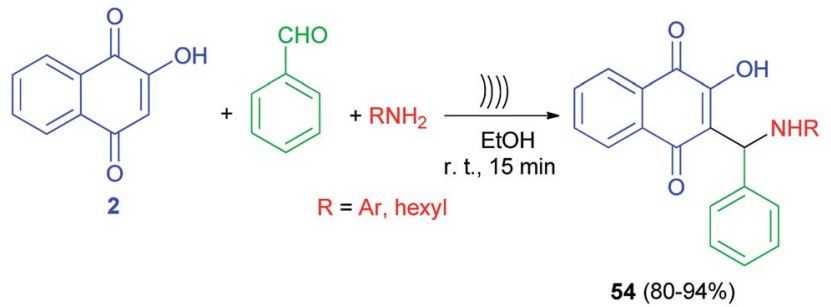

Scheme 32 Synthesis of Mannich bases 54 derived from lawsone under ultrasonic irradiation. 


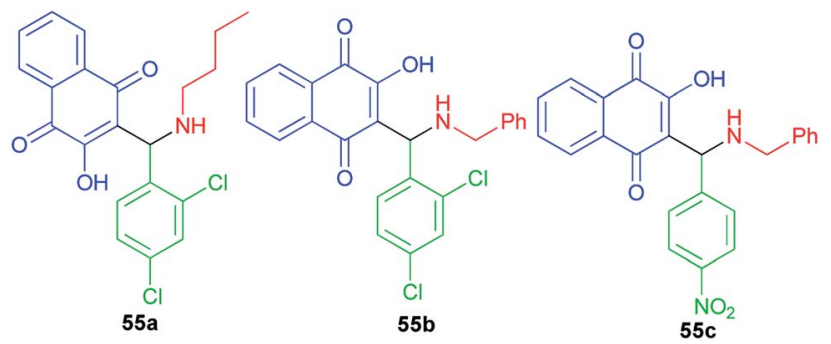

Fig. 3 Structures of 3-aminomethylnaphthoquinones $55 a-c$ active against HSV-1.

aldehydes and anilines/heterocyclic amines using montmorillonite $\mathrm{K}-10(10 \mathrm{~mol} \%)$ as a catalyst in $\mathrm{EtOH}$ at room temperature for 8-10 $\mathrm{h}$. Benzaldehydes and aromatic amines carrying both electron-donating and electron-withdrawing substituents and heterocyclic amines displayed high reactivity under this optimized conditions to afford the desired products in $81-93 \%$ yields. A speculative mechanistic explanation for this reaction is provided in Scheme 31. In the first step, aromatic amines attacked the activated benzaldehydes to form activated imines 52. The latter compounds reacted with lawsone, to give an intermediate $\mathbf{5 3}$ that underwent tautomerization to yield the products. Montmorillonite K-10 is likely to enhance the rate of Mannich reaction. ${ }^{58}$

Lopez-Lopez et al. developed a non-catalytic effective procedure to prepare Mannich base lawsone derivatives 54 in $80-94 \%$ yields using one-pot three-component reaction of lawsone (2), amines and benzaldehyde promoted by ultrasound irradiation at room temperature for $15 \mathrm{~min}$ (Scheme 32). ${ }^{59} \mathrm{~A}$ possible mechanism for the formation of $\mathbf{5 4}$ is proposed according to the first mechanism as indicated in Scheme 2.

A small series of 3-aminomethylnaphthoquinones 55a-c active against HSV-1 with low in vitro and in silico toxicity profile has been evaluated by Paixao and co-workers. In spite of the highest antiviral activity against HSV-1 of compound $55 \mathbf{b}$, the most promising molecule is probably compound $\mathbf{5 5 a}$ due to its grater SI value ( $\mathrm{SI}=\mathrm{CC}_{50} / \mathrm{EC}_{50}$ ). All compounds exhibited Lphase of lytic replication. Compounds 55a-b also inhibited IE and $\mathrm{E}$ phases to different degrees and they affect $\mathrm{gD}$ protein expression (L-phase). Structural features, such the nature of the substituent on the nitrogen atom (benzyl versus $n$-butyl) the conformation and LUMO distribution and energy profiles seem to modulate the antiviral activity of these compounds (Fig. 3). ${ }^{28}$

\section{Synthesis of aminomethylnaphthoquinone Mannich base-metal complexes}

\subsection{Complexes derived from ferrocenylalkanamines}

Ferrocenylmethylamine $\mathbf{5 6}$ was first synthesized from ferrocene carboxaldehyde by condensation of hydroxylamine on the aldehyde function followed by a reduction with $\mathrm{LiAlH}_{4}$. The amine 56 was obtained in 93\% global yield. Ferrocenyl aminohydroxynaphthoquinones $\mathbf{5 7}$, analogues of atovaquone, were
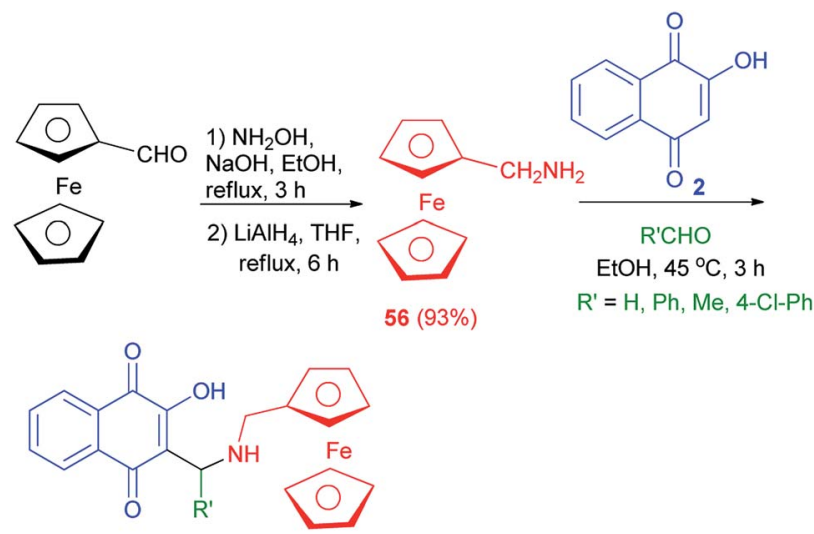

$57(60-67 \%)$

Scheme 33 Synthsis of ferrocenyl aminohydroxynaphthoquinones 57.

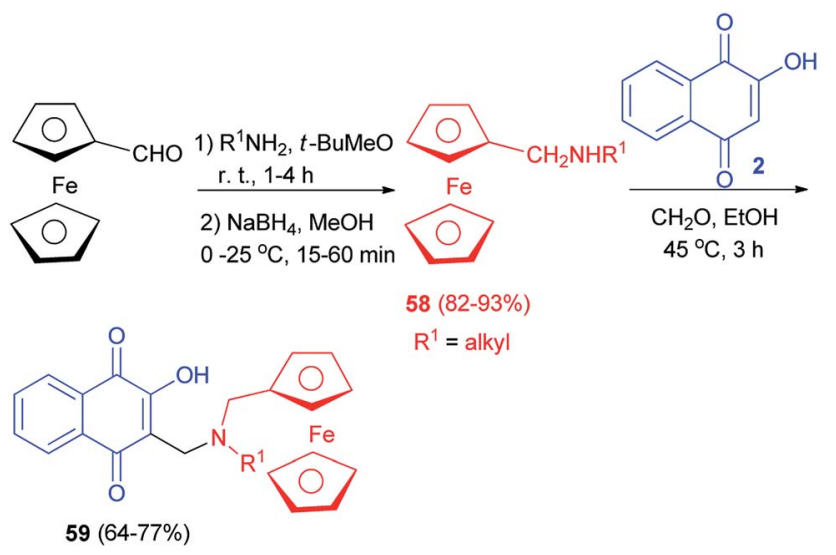

Scheme 34 Synthesis of ferrocenyl aminohydroxynaphthoquinones 59.

synthesized from 2-hydroxyquinone, ferrocenyl amines 56 and aldehydes in EtOH at $45{ }^{\circ} \mathrm{C}$ for $3 \mathrm{~h}$ in $60-67 \%$ yields (Scheme 33). ${ }^{60}$

Condensation of commercial amines on ferrocene carboxaldehyde followed by reduction with $\mathrm{NaBH}_{4}$ led to secondary ferrocenyl amines 58 in high global yield (82-93\%). The ferrocenyl derivatives $\mathbf{5 9}$ were then prepared by condensation of lawsone (2) with the formaldehyde in the presence of the corresponding ferrocenylmethylamines 59 in EtOH at $45^{\circ} \mathrm{C}$ for $3 \mathrm{~h}$. Compounds 59 were obtained in $64-77 \%$ yields (Scheme 34 ). ${ }^{60}$ Ferrocenic atovaquone derivative $\mathbf{5 9}$ composed of the hydroxynaphthoquinone core plus an amino-ferrocenic group and an aliphatic chain with 6-8 carbon atoms were found to be significantly active against $T$. gondii. Moreover, this novel compound were also effective against the atovaquone-resistant strain of $T$. gondii (AtoR). ${ }^{\mathbf{4 4}}$

Following the procedure described in the literature, ${ }^{60}$ the diamine 60 was prepared from commercially available $N, N$ dimethylaminomethylferrocene (61). The treatment of compound 60 with 2-hydroxynaphthoquinone (2) in the presence of acetaldehyde in $\mathrm{EtOH}$ at room temperature for $5 \mathrm{~h}$ afforded the compound 62 as a mixture of diastereomers in 55/ 

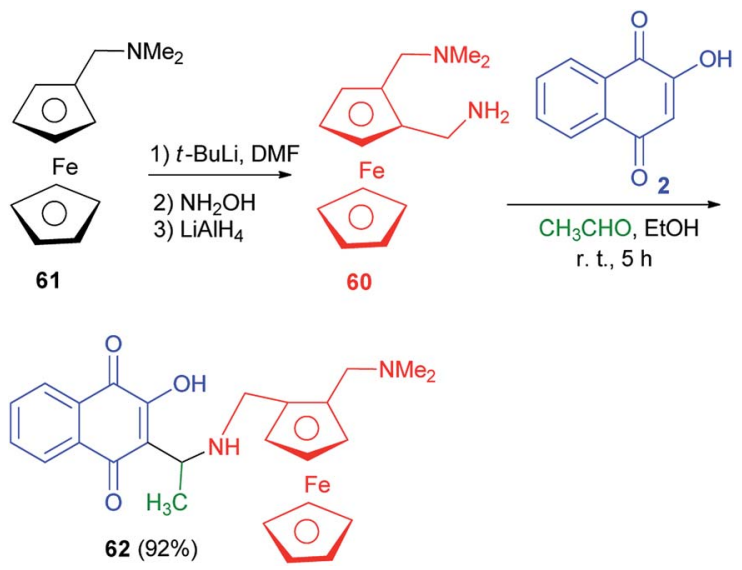

Scheme 35 Synthesis of $3\{N-(2-(N, N$-dimethylaminomethyl)ferrocenylmethyl)-1-aminoethyl\}-2-hydroxynaphthoquinone 62 .

45 ratio (92\% yield) which cannot be separated by silica gel column chromatography (Scheme 35). ${ }^{60}$

The new Mannich bases 63a-c were prepared in $57-98 \%$ yields via Mannich reaction of lawsone (2), aryl carboxaldehyde (2-pyridylcarboxaldehyde) for 63a, 4-pyridylcarboxaldehyde for 63b, and 3,4-difluorobenzaldehyde for 63c and ferrocene-1ylmethylamine (64) in EtOH at room temperature for $5 \mathrm{~h}$. Analogously, compound 63d was obtained in $25 \%$ yield from the reaction of 2 with ferrocene-1-yl carboxaldehyde and heptylamine in EtOH at room temperature for $5 \mathrm{~h}$ (Scheme 36). The 2-pyridyl derivative 63a was distinctly more active than its analogs 63b-d in breast, prostate and pancreatic cancer cells. Compound 63a also exhibited greater antiproliferative effects in the androgen-receptor negative PC-3 prostate and Pgpexpressing $\mathrm{KB}-\mathrm{V} 1 / \mathrm{Vbl}$ cervix carcinoma cell lines. Compound 63a reached sub-micromolar activities in these aggressive

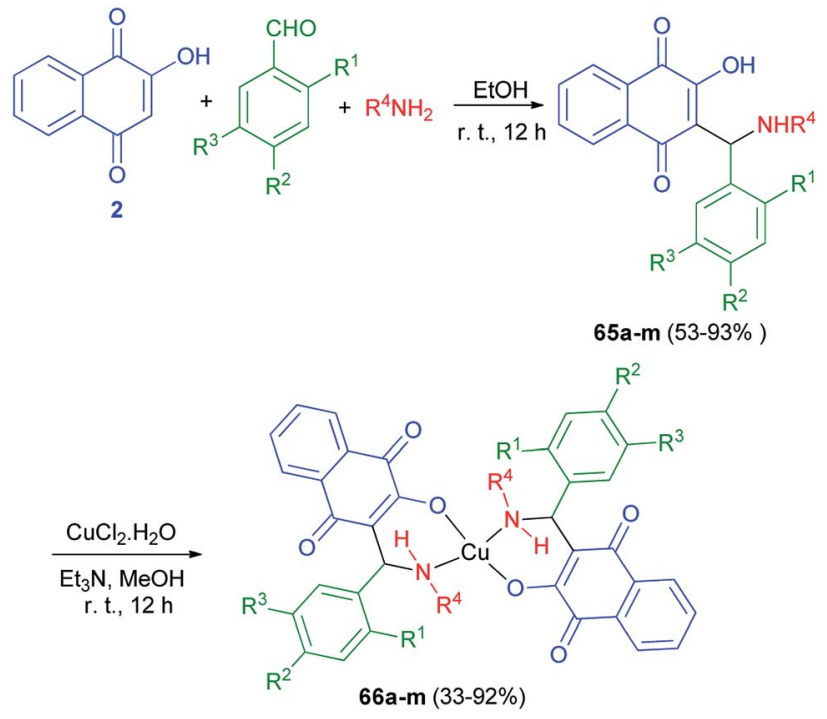

Scheme 37 Synthesis of Mannich bases of 65 and their copper complexes 66 .

cancer cells and, thus, features a promising drug candidate for the efficient treatment of hormone- or multidrug-resistant cancer types. ${ }^{22}$

\subsection{Copper complexes}

A series of novel Mannich bases 65a-m derived have been synthesized in 53-93\% yields from 2-hydroxy-1,4naphthoquinone (2), substituted benzaldehydes and various primary amines $\left(\mathrm{NH}_{2} \mathrm{R}^{4}, \mathrm{R}^{4}=n\right.$-butyl, benzyl, allyl, 2-furfuryl $)$ in EtOH at room temperature for $12 \mathrm{~h}$ in the dark. Followed, their $\mathrm{Cu}^{2+}$ complexes 66a-m have been prepared in $33-92 \%$ yields from the reaction of the compounds $65 \mathrm{a}-\mathrm{m}$ with $\mathrm{CuCl}_{2} \cdot 2 \mathrm{H}_{2} \mathrm{O}$ in<smiles>[R]c1ccc(C=O)c([R])c1[18O]C1=CC(=O)c2ccccc2C1=O</smiles>

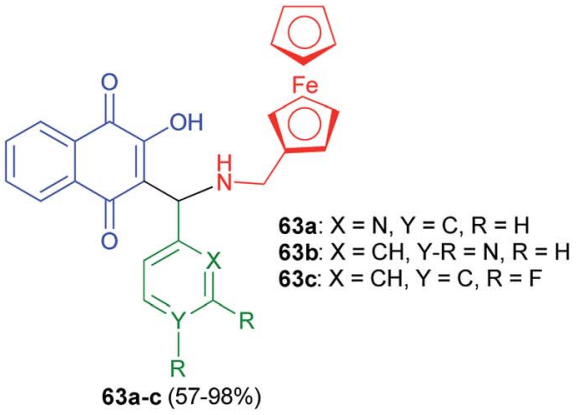

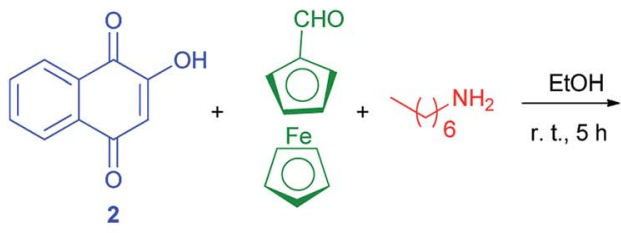<smiles>CCCCCCCNC(C1=C(O)C(=O)c2ccccc2C1=O)c1ccc2ccccc2c1</smiles>

Scheme 36 Ferrocene modified lawsone Mannich bases 63 . 


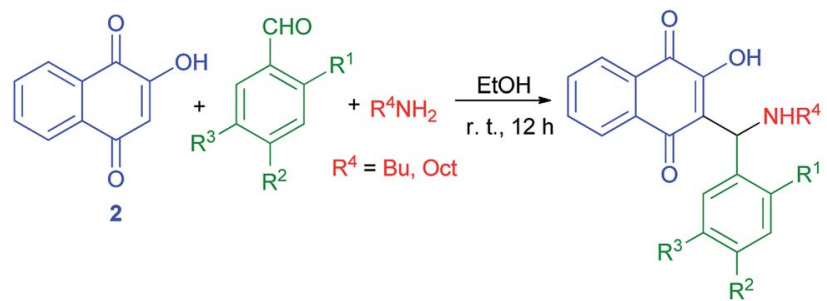
$67(70-95 \% \%)$

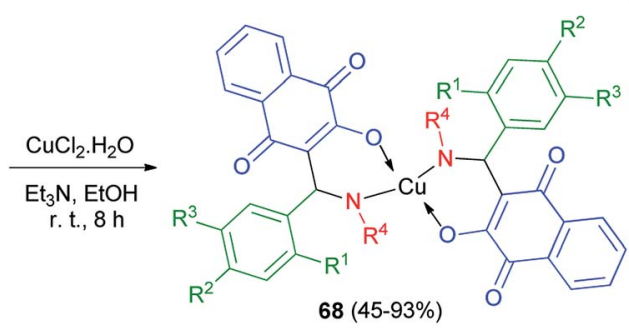

Scheme 38 Synthesis of Mannich bases 67 and their copper complexes 68 .

$\mathrm{MeOH}$ in the presence of $\mathrm{Et}_{3} \mathrm{~N}$ in the dark for $12 \mathrm{~h}$ at room temperature (Scheme 37). The antimicrobial activity of all compounds has been tested. In general, Mannich bases were more active than complexes, $65 \mathbf{k}\left(\mathrm{R}^{1}=\mathrm{OH} ; \mathrm{R}^{2}=\mathrm{H} ; \mathrm{R}^{3}=\mathrm{Me} ; \mathrm{R}^{4}\right.$ $=\mathrm{Bn})$ and $65 \mathrm{~m}\left(\mathrm{R}^{1}=\mathrm{OH} ; \mathrm{R}^{2}=\mathrm{H} ; \mathrm{R}^{3}=\mathrm{Br} ; \mathrm{R}^{4}=\mathrm{Bn}\right)$ being the most potent inhibitors. The MIC for the most active compound 65k against $S$. Coli was $20 \mu \mathrm{mol} \mathrm{L}{ }^{-1}\left(8 \mu \mathrm{g} \mathrm{mL} \mathrm{m}^{-1}\right)$, better than chloramphenicol $\left(90 \mu \mathrm{mol} \mathrm{L^{-1 }}\right)$ and well below most values reported for other naphthoquinones. ${ }^{25}$
A new series of Mannich bases 67 derived from 2-hydroxy1,4-naphthoquinone (2), substituted benzaldehydes and two primary amines, and their $\mathrm{Cu}^{2+}$ complexes $\mathbf{6 8}$ were synthesized by Cardoso and co-workers. At the first stage, 2-hydroxy-1,4naphthoquinone (2) undergo an amino alkylation with butylamine or octylamine and benzaldehydes in $\mathrm{EtOH}$ at room temperature for $12 \mathrm{~h}$, which led to lawsone derivatives 67 in high yields 70-95\%. Complexes 68 were obtained by addition of triethylamine to an ethanolic suspension of compounds 68 and $\mathrm{CuCl}_{2} \cdot 2 \mathrm{H}_{2} \mathrm{O}$ under stirring at room temperature for $8 \mathrm{~h}$, with yields varying from 45 to $93 \%$ (Scheme 38). Compounds 68 evaluated for their potential as selective cholinesterase inhibitors (ChEIs). Eight copper complexes were identified and characterized as potent reversible and selective ChEIs with inhibitory potencies $\left(\mathrm{IC}_{50}\right)$ and constants of inhibition $\left(K_{\mathrm{i}}\right)$ ranging from 1.24 to $11.5 \mu \mathrm{mol} \mathrm{L}{ }^{-1}$. One of the compounds was particularly promising, showing $\mathrm{IC}_{50}$ and $K_{\mathrm{i}}$ values of $1.24 \pm$ 0.01 and $1.06 \pm 0.01 \mu \mathrm{mol} \mathrm{L}{ }^{-1}$, respectively, for huAChE. ${ }^{26}$

A novel versatile tridentate 3-(aminomethyl)naphthoquinone proligand, 3-[N-(2-pyridylmethyl)aminobenzyl]-2hydroxy-1,4-naphthoquinone (69), was obtained from the Mannich reaction of 2-hydroxy-1,4-naphthoquinone (2) with 2aminomethylpyridine and yielded a polymeric compound 70 in $57 \%$ yield. When the reaction mixture was left stirring under the same conditions for over $5 \mathrm{~h}$ benzaldehyde in $\mathrm{EtOH}$ at $22^{\circ} \mathrm{C}$ for $5 \mathrm{~h}$ in $68 \%$ yield. The reactions of 69 with $\mathrm{CuCl}_{2} \cdot 2 \mathrm{H}_{2} \mathrm{O}$ in the presence of $\mathrm{Et}_{3} \mathrm{~N}$ in $\mathrm{MeOH}$ at $30{ }^{\circ} \mathrm{C}$ yielded a polymeric compound 70 in $57 \%$ yield. When the reaction mixture was left

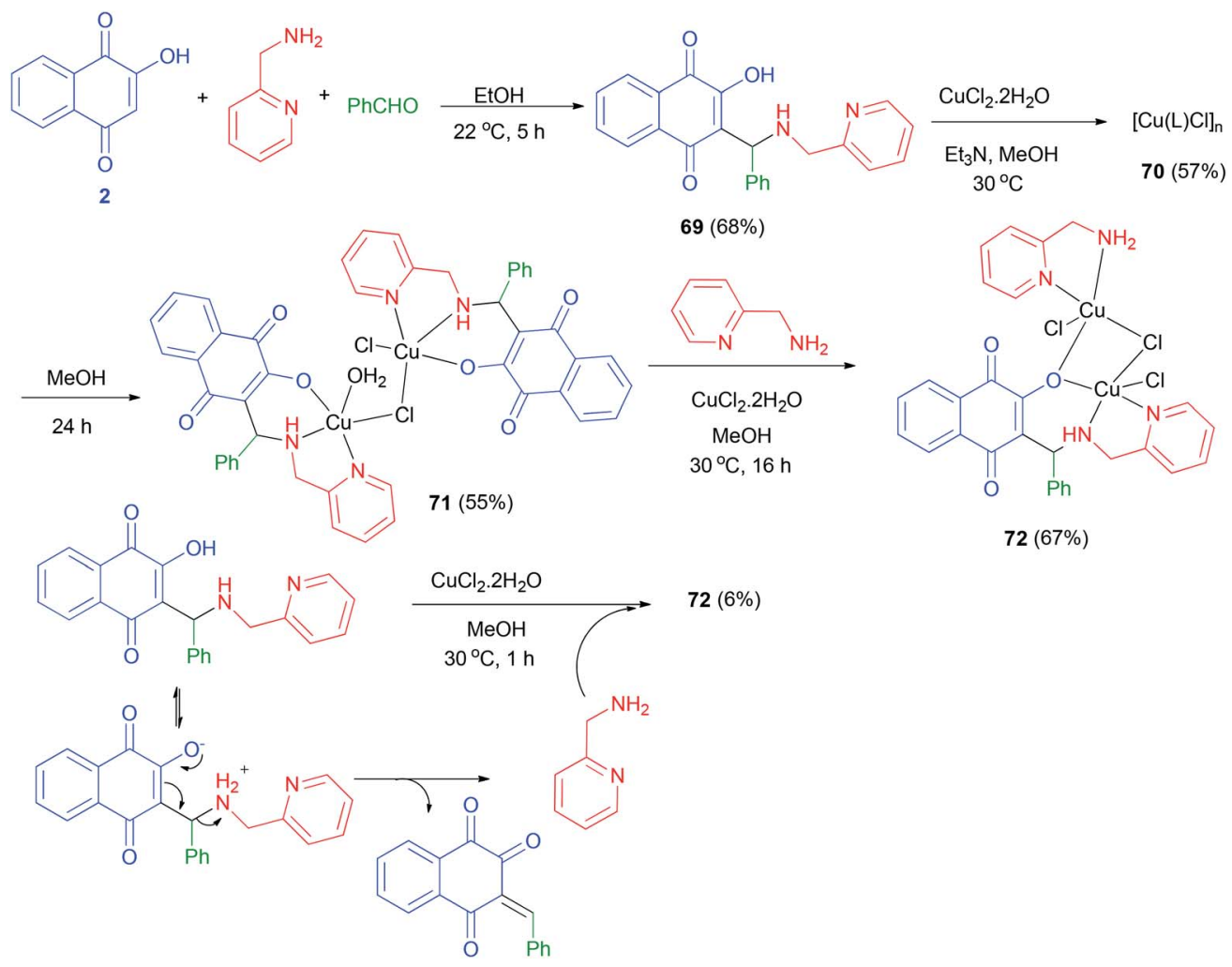

Scheme 39 Synthesis of Mannich base 69 and their complexes 71 and 72 


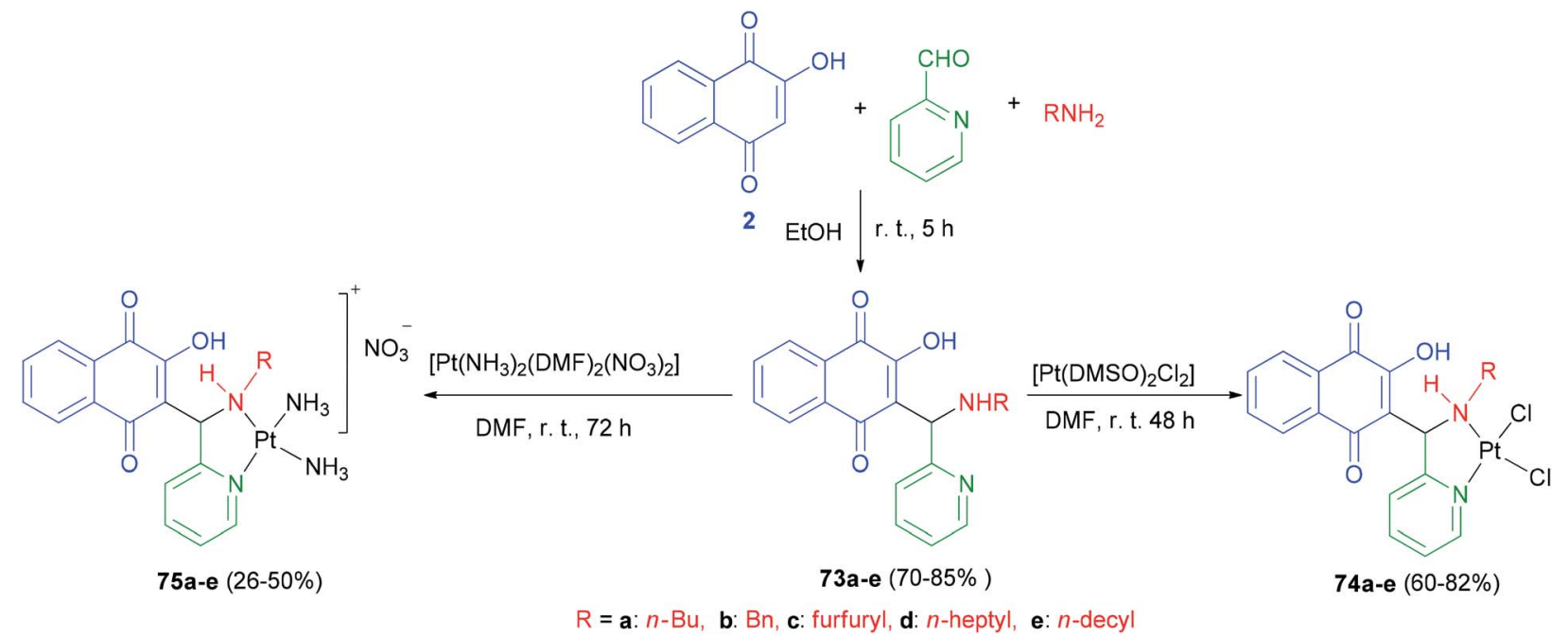

Scheme 40 Synthesis of 3-(aminomethyl)naphthoquinones 73 and their Pt-complexes 74 and 75.

stirring under the same conditions for over $5 \mathrm{~h}$ darkening was observed. Dark green solid 71 isolated after $24 \mathrm{~h}$ in $55 \%$ yield. The reaction of complex $\mathbf{7 1}$ with 2-aminomethylpyridine in using $\mathrm{CuCl}_{2} \cdot 2 \mathrm{H}_{2} \mathrm{O}$ in $\mathrm{MeOH}$ at $30{ }^{\circ} \mathrm{C}$ for $16 \mathrm{~h}$ in afforded complex 72 in $67 \%$ yield. Complex 72 could also be obtained in $6 \%$ yield from decomposition of 69 in methanol using $\mathrm{CuCl}_{2}-$ $\cdot 2 \mathrm{H}_{2} \mathrm{O}$ at $30^{\circ} \mathrm{C}$ for $1 \mathrm{~h}$ (Scheme 39$) .{ }^{61}$

\subsection{Platinum complexes}

The first examples of platinum(II) complexes of 3-(aminomethyl) naphthoquinone Mannich bases 73 have been synthesized by Vargas and coworkers. Proligands $3-\left[\left(\mathrm{R}^{1}\right.\right.$-amino)(pyridin-2-yl) methyl]-2-hydroxy-1,4-naphthoquinones $(\mathrm{R}=n$-Bu, 73a; $\mathrm{Bn}$, 73b; furfuryl, 73c; $n$-heptyl, 73d and $n$-decyl, 73e) were synthesized in $70-85 \%$ yields from the Mannich reactions of lawsone (2) with the respective primary amines and 2-pyridinecarboxyaldehyde, in ethanol, under stirring, at room temperature for $5 \mathrm{~h}$. The reactions of equimolar amounts of 73a-e and cis$\left[\mathrm{Pt}(\mathrm{DMSO})_{2} \mathrm{Cl}_{2}\right]$ in dimethylformamide (DMF) at room temperature for $48 \mathrm{~h}$ in the dark yielded the chlorido complexes cis-[ $\left.\mathrm{Pt}(\mathbf{7 4 a}-\mathbf{e}) \mathrm{Cl}_{2}\right]$ 74a-e in $60-82 \%$ yields as yellow solids (Scheme 40).

The amino complexes cis-[Pt(75a-e $\left.)\left(\mathrm{NH}_{3}\right)_{2}\right] \mathrm{NO}_{3}$ 75a-e were obtained as orange powders in $26-50 \%$ yields from the reactions of the solid proligands $73 a-e$ with a solution of cis$\left[\mathrm{Pt}\left(\mathrm{NH}_{3}\right)_{2}(\mathrm{DMF})_{2}\right]\left(\mathrm{NO}_{3}\right)_{2}$ in DMF at room temperature in the dark for $72 \mathrm{~h}$ (Scheme 40). The cytotoxic activities of all compounds have been tested for different cancer cell lines. Proligands 73d and 73e have exhibited high activity against the tested cell lines, although they were only moderately active against the PC-3 cell line $\left(\mathrm{IC}_{50}=29.9\right.$ and $15.6 \mathrm{mmol} \mathrm{L}^{-1}$, respectively). In general the compounds with the longest carbon chains $(\mathrm{R}=n$-heptyl and $n$-decyl $)$ have exhibited the highest activities. $^{62}$

2-Hydroxy-3-(aminomethyl)-1,4-naphthoquinones 73a,d,e derivatives, chlorido 74a,d,e and amino $\mathbf{7 5 a}, \mathbf{d}, \mathbf{e} \mathrm{Pt}^{2+}$ complexes were synthesized as described in the literature. ${ }^{44}$ The DMF solutions of compounds $\left[\mathrm{Pt}(73 \mathbf{a}, \mathbf{d}, \mathbf{e})(\mathrm{DMF})_{2}\right]\left(\mathrm{NO}_{3}\right)_{2}$ were obtained by reacting a solution of $\mathrm{AgNO}_{3}$ with $73 \mathbf{a}, \mathbf{d}, \mathbf{e}$ in DMF at $50{ }^{\circ} \mathrm{C}$ for $24 \mathrm{~h}$. $\left[\mathrm{Pt}(76 \mathbf{6 a}, \mathbf{d}, \mathbf{e})\left(\mathrm{H}_{2} \mathrm{O}\right)_{2}\right]\left(\mathrm{NO}_{3}\right)_{2} 76 \mathbf{7 6}, \mathbf{d}, \mathbf{e}$ were obtained by dilution of the DMF solutions with water to a final concentration of $95: 5 \quad\left(\mathrm{H}_{2} \mathrm{O}: \mathrm{DMF}\right)$. The water solution of $\left[\mathrm{Pt}(68 \mathrm{a})\left(\mathrm{H}_{2} \mathrm{O}\right)_{2}\right]\left(\mathrm{NO}_{3}\right)_{2}$ 76a was also prepared using the same procedure above, except for the use of $\mathrm{H}_{2} \mathrm{O}$ instead of DMF, for the gel mobility shift assays (Fig. 4). Several chlorido and amino $\mathrm{Pt}^{2+} \quad$ complexes of 2-hydroxy-3-(aminomethyl)-1,4naphthoquinone Mannich bases 73a,d,e exhibiting moderate to high cytotoxicity against cancer cell lines were studied in order to investigate their modes of DNA binding, in vitro DNA strand breaks, mechanism of topoisomerase (Topo I) inhibition and cellular accumulation. DNA model base studies have shown that complex 74a was capable of binding covalently to 9-ethylguanine (9-EtG) and $5^{\prime}$-GMP. The chlorido $\mathrm{Pt}^{2+}$ complexes 74a,d,e highly accumulate in prostate (PC-3) and melanoma (MDA-MB-435) cell lines, being able to induce DNA strand

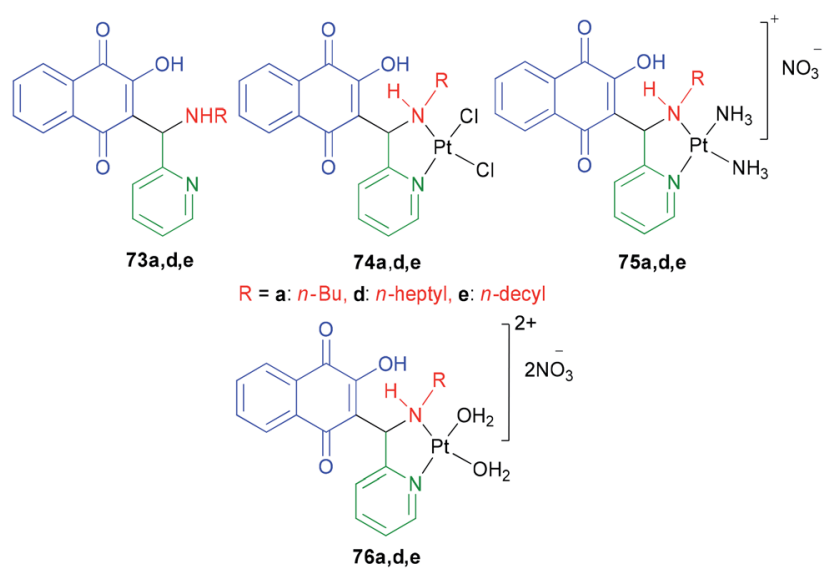

Fig. 4 Structures of 2-hydroxy-3-(aminomethyl)-1,4-naphthoquinones 73 and their $\mathrm{Pt}^{2+}$ complexes $74,75,76 a, d, e$. 
<smiles>[R]NC(CNC)C1=C(O)C(=O)c2ccccc2C1=O</smiles>

73

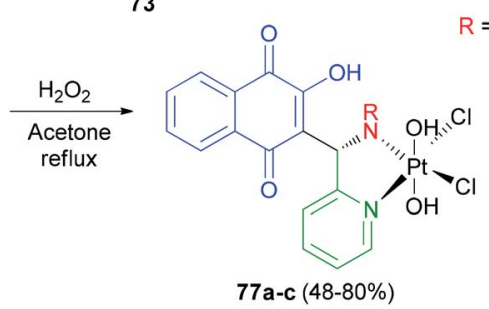

Scheme 41 Synthesis of Mannich base-platinum(Iv) complexes 77a-c.

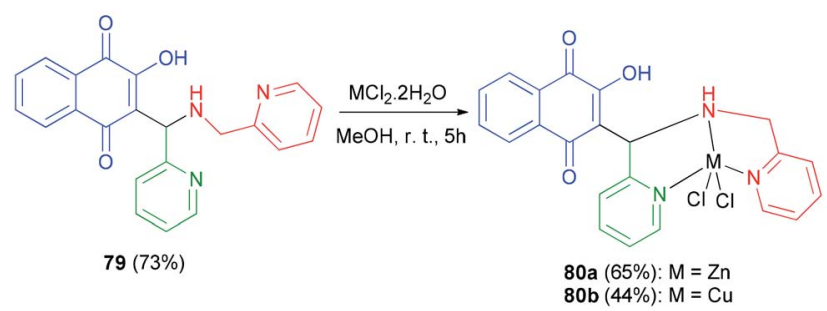

Scheme 42 Synthesis of Mannich base 79 and complexes 80a-b.

breaks in vitro and inhibit Topo I by a catalytic mode. On the other hand, the free 2-hydroxy-3-(aminomethyl)-1,4naphthoquinones 73a,d,e and the amino $\mathrm{Pt}^{2+}$ complexes 75a,d,e neither cause DNA strand breakage nor exhibit strong DNA interaction, nevertheless the latter were also found to be catalytic inhibitors of Topo I at $100 \mu \mathrm{M}$. Thus, coordination of the Mannich bases 73a,d,e to the " $\mathrm{PtCl}_{2}$ " fragment substantially affects the chemical and biophysical properties of the proligands, leading to an improvement of their DNA binding properties and generating compounds that cleave DNA and catalytically inhibit Topo I. Finally, the high cytotoxicity exhibited by the free (uncomplexed) 2-hydroxy-3(aminomethyl)-1,4-naphthoquinones 73a,d,e might be associated with their decomposition in solution, which is not observed for the $\mathrm{Pt}^{2+}$ complexes. ${ }^{63}$

Vargas et al. described synthesis of three novel platinum(Iv) complexes cis,cis,trans $\left[\mathrm{Pt}(77 \mathbf{a}-\mathbf{c}) \mathrm{Cl}_{2}(\mathrm{OH})_{2}\right] \quad 77 \mathbf{a}-\mathbf{c}(77=2-$ hydroxy-3-[(R-amino)(pyridin-2-yl)methyl]-1,4-naphthoquinone, $\mathrm{R}=n$-butyl, 77a; $n$-heptyl, 77b and $n$-decyl, 77c). In this process, the yellow-orange complexes $77 \mathbf{a}-\mathbf{c}$ were obtained by selective oxidation of 78a-c with $\mathrm{H}_{2} \mathrm{O}_{2}(30 \%)$ in refluxing acetone for $7 \mathrm{~h}$ in $48-80 \%$ yields (Scheme 41 ). The cytotoxicity studies against
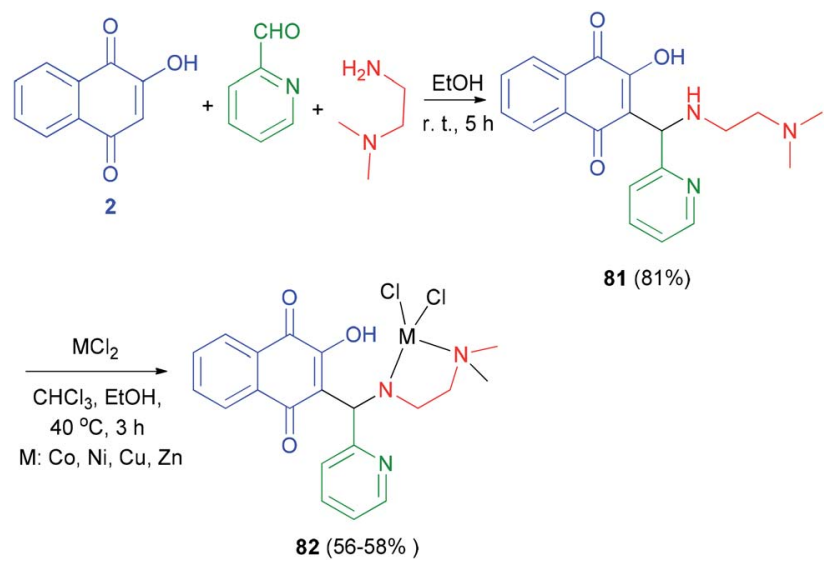

Scheme 43 Metal(II) complexes of Mannich base derived from lawsone 82 .

four human cancer cell lines have shown that in general the platinum(Iv) and platinum(II) derivatives exhibit the same cytotoxic profile and are all more active than cisplatin. The lowest in vitro $\mathrm{IC}_{50}$ values have been observed for $\mathbf{7 7 b} \mathbf{b}$, which bear ligands with the largest $\mathrm{R}$ groups being the most lipophilic. Furthermore similar $\mathrm{IC}_{50}$ values for platinum(II) and platinum(Iv) complexes of the same ligands have been associated with rapid in vitro reduction of the latter complexes to afford $77 \mathbf{a}-\mathbf{c}^{64}$

\subsection{Other-types metal complexes}

Tridentate Mannich base $\mathbf{7 9}$ derived from lowsone, pyridine carboxyaldehyde and 2-aminomethylpyridine, have been synthesized in EtOH at room temperature in the dark for $22 \mathrm{~h}$ in 73\% yield. Dichloro\{3-[N-(2-pyridylmethyl)aminomethyl-2-pyridyl]-2-hydroxy-1,4-naphthoquinone\}zinc(II) 80a was obtained from the reaction of 79 with 1 equiv. $\mathrm{ZnCl}_{2} \cdot 2 \mathrm{H}_{2} \mathrm{O}$ in methanol at room temperature in the dark for $5 \mathrm{~h}$ in $65 \%$ yield. The analogous dichloro 3-[N-(2-pyridylmethyl)aminomethyl-2-pyridyl]-2hydroxy-1,4-naphthoquinone copper(II) complex 80b was obtained from equimolar amounts of 79 and $\mathrm{CuCl}_{2} \cdot 2 \mathrm{H}_{2} \mathrm{O}$ in methanol at room temperature for $5 \mathrm{~h}$ in $44 \%$ yield (Scheme $42)^{65}$

The Mannich base ligand $\mathbf{8 1}$ has been synthesized in $81 \%$ from lawsone, pyridine-2-carbaldehyde and $N, N$-dimethylethylenediamine in EtOH at room temperature for $5 \mathrm{~h}$. Ligand $\mathbf{8 1}$ was dissolved in chloroform and then corresponding metal chloride (Co(II), $\mathrm{Cu}$ (II), Ni(II) and $\mathrm{Zn}(\mathrm{II})$ ) dissolve in ethanol was added drop wise and stirred at $40{ }^{\circ} \mathrm{C}$ for $3 \mathrm{~h}$ afforded metal(II) complexes of Mannich base 82 in $56-58 \%$ yields (Scheme 43 ). ${ }^{66}$

\section{Conclusions}

Aminomethylnaphthoquinone Mannich bases derived from lawsone and their metal complexes belong to an important class of organic/organometallic compounds and exhibit a wide range of biological properties and due to their potent activities, thus thesynthesis of Mannich bases derived from lawsone is an area 
of current interest. Several multi-component reactions for the synthesis of aminomethylnaphthoquinones have been reported from lawsone, aldehydes and amines using green solvents, Bronsted and Lewis acid catalysts, ionic liquids, ultrasound irradiation under room temperature, reflux and solvent-free conditions. Also, Metal complexes of 3-(aminomethyl)naphthoquinone Mannich bases have been synthesized from lowsone, aldehydes and organometallic amines or the reaction of Mannich bases with metal cations under different conditions. This review summarizes the most multi-component strategies in the synthesis of aminomethylnaphthoquinone Mannich bases derived from lawsone and their metal complexes and applications.

\section{Conflicts of interest}

There are no conflicts to declare.

\section{Acknowledgements}

The authors thank the Research Council of Payame Noor University and Islamic Azad University (Takestan Branch and Buinzahra Branch).

\section{Notes and references}

1 Y. Kumagai, Y. Shinkai, T. Miura and A. K. Cho, Annu. Rev. Pharmacol. Toxicol., 2012, 52, 221-247.

2 L. Mafioleti, I. F. Silva Junior, E. M. Colodel, A. Flach and D. T. O. Martins, J. Ethnopharmacol., 2013, 150, 576-582.

3 A. M. Pinto, J. P. Leite, A. P. Neves, G. B. da Silva, M. D. Vargas and I. C. Paixao, Arch. Virol., 2014, 159, 1827-1833.

4 A. C. Dweck, Int. J. Cosmet. Sci., 2002, 24, 287-302.

5 V. A. Motz, C. P. Bowers, L. M. Young and D. H. Kinder, J. Ethnopharmacol., 2012, 143, 314-318.

6 D. C. Mcmillan, S. D. Sarvate, J. E. Oatis Jr and D. J. Jollow, Toxicol. Sci., 2004, 82, 647-655.

7 J. Araldi and S. S. Guterres, Infarma, 2005, 17, 78-83.

8 A. E. Musa, B. Madhan, W. Madhulatha, J. R. Rao, G. A. Gasmelseed and S. Sadulla, J. Am. Leather Chem. Assoc., 2009, 104, 183-190.

9 M. Dogru, Z. Baysal and C. Aytekin, Prep. Biochem. Biotechnol., 2006, 36, 215-221.

10 S. Ali, T. Hussain and R. J. Nawaz, J. Clean. Prod., 2009, 17, 61-66.

11 A. Kosmalska, M. Zaborski and A. Masek, Przem. Chem., 2010, 89, 420-424.

12 A. C. Watkinson, K. R. Brian, K. A. Walters and J. Hadgraft, Int. J. Cosmet. Sci., 1992, 14, 265-275.

13 R. R. Korac and K. M. Khambholja, Pharmacogn. Rev., 2011, 5, 164-173.

14 R. Andoong and H. Chihchiang, Environ. Sci. Technol., 2005, 39, 7460-7468.

15 R. A. Doong and Y. J. Lai, Water Res., 2005, 39, 2309-2318.

16 A. Ostovari, S. M. Hoseinieh, M. Peikari, S. R. Shadizadeh and S. J. Hashemi, Corros. Sci., 2009, 51, 1935-1949.
17 A. Y. El-Etre, M. Abdallah and Z. E. El-Tantawy, Corros. Sci., 2005, 47, 385-395.

18 Y. M. Hijji, B. Barare and Y. Zhang, Sens. Actuators, B, 2012, 169, 106-112.

19 M. N. Rahmoun, M. Benabdallah, D. Villemin, K. Boucherit, B. Mostefa-Kara, C. Ziani-Cherif and N. Choukchou-Braham, Der Pharma Chem., 2010, 2, 320-326.

20 H. S. Muhammad and S. Muhammad, Afr. J. Biotechnol., 2005, 4, 934-937.

21 D. Anju, S. Kavita, G. Jugnu, G. Munish and S. Asha, J. Pharm. Sci. Innovation, 2012, 1, 17-20.

22 A. Ahmad, K. Mahal, S. Padhye, F. H. Sarkar, R. Schobert and B. Biersack, J. Saudi Chem. Soc., 2017, 21, 105-110.

23 M. Arundhati, C. Dipak and R. Mithun, Indian J. Pharm. Educ. Res., 2018, 52, 472-479.

24 N. M. F. Lima, C. S. Correia, P. A. L. Ferraz, A. V. Pinto, M. do C. R. F. Pinto, A. E. G. Santana and M. O. F. Goulart, J. Braz. Chem. Soc., 2002, 13, 822-829.

25 A. P. Neves, C. C. Barbosa, S. J. Greco, M. D. Vargas, L. C. Visentin, C. B. Pinheiro, A. S. Mangrich, J. P. Barbosa and G. L. da. Costae, J. Braz. Chem. Soc., 2009, 20, 712-727.

26 A. F. L. Vilela, B. M. Frugeri, A. L. F. Sarria, R. O. S. Kitamura, J. B. Fernandes, M. F. G. F. Silva, Q. B. Cass and C. L. Cardoso, J. Braz. Chem. Soc., 2016, 27, 535-545.

27 T. T. Guimaraes, F. R. Maria do Carmo, J. S. Lanza, M. N. Melo, L. Rubens, I. M. de Melo, E. B. Diogo, V. F. Ferreira, C. A. Camara, W. O. Valenca, R. N. de Oliveira, F. Frezard and E. N. da Silva Junior, Eur. J. Med. Chem., 2013, 63, 523-530.

28 C. P. P. de Mello, N. S. Sardoux, L. Terra, L. C. Amorim, M. D. Vargas, G. B. da Silva, H. C. Castro, V. A. Giongo, L. F. Madeira and I. C. N. P. Paixao, Antiviral Ther., 2016, 21, 507-515.

29 J. F. Allochio Filho, L. L. Roldi, M. Delarmelina, R. G. Fiorot, J. T. Andrade, Á. A. Aleixo, R. S. Carvalho, M. G. F. Araújo, J. M. S. Ferreira, A. G. Taranto, W. Romao and S. J. Greco, J. Braz. Chem. Soc., 2016, 27, 2127-2140.

30 K. Mahal, A. Ahmad, F. Schmitt, J. Lockhauserbäumer, K. Starz, R. Pradhan, S. Padhye, F. H. Sarkar, W. S. Koko, R. Schobert, K. Ersfeld and B. Biersack, Eur. J. Med. Chem., 2017, 126, 421-431.

31 M. Dabiri, Z. Noroozi Tisseh and A. Bazgir, Dyes Pigm., 2011, 89, 63-69.

32 M. Leffler and R. Hathaway, J. Am. Chem. Soc., 1948, 70, 3222-3223.

33 C. E. Dalgliesh, J. Am. Chem. Soc., 1949, 71, 1697-1702.

34 S. C. Hooker, J. Am. Chem. Soc., 1936, 58, 1190-1197.

35 E. N. da Silva Júnior, I. M. M. de Melo, E. B. T. Diogo, V. A. Costa, J. D. de Souza Filho, W. O. Valenca, C. A. Camara, R. N. de Oliveira, A. S. de Araujo, F. S. Emery, M. R. dos Santos, C. A. de Simone, R. F. S. Menna-Barreto and S. L. de Castro, Eur. J. Med. Chem., 2012, 52, 304-312.

36 M. H. C. Lagrota, M. D. Wigg, M. G. M. do Santos, A. V. Pinto and M. C. F. R. Pinto, Rev. Microbiol., 1988, 19, 338-342. 
37 A. F. dos Santos, P. A. L. Ferraz, A. V. Pinto, M. C. F. R. Pinto, M. O. F. Goulart and A. E. G. SantAna, Int. J. Parasitol., 2000, 30, 1199-1202.

38 N. B. de Souza, I. M. de Andradel, P. F. Carneiro, G. A. M. Jardim, I. M. M. de Melo, E. N. da Silva Júnior and A. U. Krettli, Mem. Inst. Oswaldo Cruz, 2014, 109, 546552.

39 W. Paengsri, V. S. Lee, W. L. Chong, H. A. Wahab and A. Baramee, Int. J. Biol. Chem., 2012, 6, 69-88.

40 T. Ndior, C. M. Ndiaye, F. D. Faye and A. Samb, Asian J. Chem., 2015, 27, 4063-4066.

41 G. B. da Silva, A. P. Neves, M. D. Vargas, J. D. B. MarinhoFilho and L. V. Costa-Lotufo, Bioorg. Med. Chem. Lett., 2016, 26, 3537-3543.

42 I. Al Nasr, J. Jentzsch, I. Winter, R. Schobert, K. Ersfeld, W. S. Koko, A. A. H. Mujawah, T. A. Khan and B. Biersack, Arch. Pharm., 2019, 352, 1900128.

43 P. Nariya, F. Shukla, H. Vyas, R. Devkar and S. Thakore, Synth. Commun., 2020, 50, 1724-1735.

44 C. Biot, G. Glorian, L. Maciejewski, J. Brocard, O. Domarle, G. Blampain, P. Millet, A. J. Georges, H. Abessolo, D. Dive and J. Lebibi, J. Med. Chem., 1997, 40, 3715-3718.

45 M. A. Gouda, H. F. Eldien, M. M. Girges and M. A. Berghot, Med. Chem., 2013, 3, 2228-2232.

46 R. G. Fiorot, A. J. F. Filho, T. M. C. Pereira, V. Lacerda Jr, R. B. dos Santos, W. Romao and S. J. Greco, Tetrahedron Lett., 2014, 55, 4373-4377.

47 J. F. Allochio Filho, R. G. Fiorot, V. Lacerda Jr, R. B. dos Santos, G. Vanini, W. Romao and S. J. Greco, Colloids Interface Sci. Commun., 2015, 4, 14-18.

48 D. Liu, S. Zhou and J. Gao, Synth. Commun., 2014, 44, 12861290.

49 M. O. B. Sousa, M. D. Vargas and F. S. Miranda, J. Mol. Struct., 2018, 1164, 260-272.

50 S. Golmakaniyoon, V. R. Askari, K. Abnous, A. Zarghi and R. Ghodsi, Iran. J. Pharm. Res., 2019, 18, 16-29.

51 H. R. Shaterian and M. Mohammadnia, J. Mol. Liq., 2013, 177, 353-360.
52 H. Naeimi and M. Farahnak Zarabi, Tetrahedron, 2018, 74, 2314-2323.

53 B. Asadi, I. Mohammadpoor-Baltork, S. Tangestaninejad, M. Moghadam, V. Mirkhani and A. Landarani-Isfahani, New J. Chem., 2016, 40, 6171-6184.

54 M. Ayaz and B. Westermann, Synlett, 2010, 10, 1489-1492.

55 H. R. Shaterian and F. Moradi, Res. Chem. Intermed., 2015, 41, 291-297.

56 P. Saluja, J. M. Khurana, K. Nikhil and P. Roy, RSC Adv., 2014, 4, 34594-34603.

57 S. Shaabani, M. R. Naimi-Jamal and A. Maleki, Dyes Pigm., 2015, 122, 46-49.

58 S. Jayashree and K. Shivashankar, Synth. Commun., 2018, 48, 1805-1815.

59 L. I. Lopez-Lopez, S. D. Nery-Flores, A. Saenz-Galindo and D. de Loera, Synth. Commun., 2017, 47, 2247-2253.

60 A. Baramee, A. Coppin, M. Mortuaire, L. Pelinski, S. Tomavo and J. Brocard, Bioorg. Med. Chem., 2006, 14, 1294-1302.

61 A. P. Neves, K. C. B. Maia, M. D. Vargas, L. C. Visentin, A. 3 Casellato, M. A. Novak and A. S. Mangrich, Polyhedron, 2010, 29, 2884-2891.

62 A. P. Neves, G. B. da Silva, M. D. Vargas, C. B. Pinheiro, C. Visentin Ldo, J. D. B. M. Filho, A. J. Araujo, L. V. CostaLotufo, C. Pessoa and M. O. de Moraes, Dalton Trans., 2010, 39, 10203-10216.

63 A. P. Neves, M. X. G. E. J. Pereira Peterson, R. Kipping, M. D. Vargas, F. P. Silva Jr, J. W. M. Carneiro and N. P. Farrell, J. Inorg. Biochem., 2013, 119, 54-64.

64 G. B. da Silva, A. P. Neves, M. D. Vargas, W. A. Alves, J. D. B. Marinho-Filho, C. Pessoa, M. O. Moraes and L. V. Costa-Lotufo, J. Braz. Chem. Soc., 2013, 24, 675-684.

65 A. P. Neves, M. D. Vargas, C. A. Tellez Soto, J. M. Ramos, C. Visentin Ldo, C. B. Pinheiro, A. S. Mangrich and E. I. P. de Rezende, Spectrochim. Acta, Part A, 2012, 94, 152-163.

66 M. Suganthi and K. P. Elango, J. Biomol. Struct. Dyn., 2019, 37, 1136-1145. 